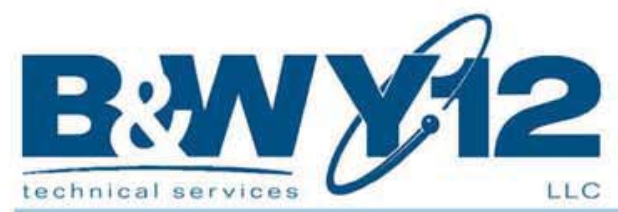

\title{
Y-12 GROUNDWATER PROTECTION PROGRAM MONITORING OPTIMIZATION PLAN FOR GROUNDWATER MONITORING WELLS AT THE \\ U.S. DEPARTMENT OF ENERGY Y-12 NATIONAL SECURITY COMPLEX, OAK RIDGE, TENNESSEE Revision 2
}

Y-12 NATIONAL
SECURITY
COMPLEX

\author{
September 2013
}

Prepared by

\author{
ELVADO ENVIRONMENTAL LLC \\ Under Subcontract No. 4300087609
}

$$
\text { for the }
$$

Environmental Compliance Department Environment, Safety, and Health Division Y-12 National Security Complex

Oak Ridge, Tennessee 37831

\section{Managed by}

Babcock \& Wilcox Technical Services Y-12, LLC for the U.S. DEPARTMENT OF ENERGY under contract No. DE-AC05-00OR22800 


\section{DISCLAIMER}

This report was prepared as an account of work sponsored by an agency of the United States Government. Neither the United States Government nor any agency thereof, nor any of their employees, makes any warranty, express or implied, or assumes any legal liability or responsibility for the accuracy, completeness, or usefulness of any information, apparatus, product, or process disclosed, or represents that its use would not infringe privately owned rights. Reference herein to any specific commercial product, process, or service by trade name, trademark, manufacturer, or otherwise, does not necessarily constitute or imply its endorsement, recommendation, or favoring by the United States Government or any agency thereof. The views and opinions of authors expressed herein do not necessarily state or reflect those of the United States Government or any agency thereof. 


\section{Y-12 GROUNDWATER PROTECTION PROGRAM MONITORING OPTIMIZATION PLAN FOR GROUNDWATER MONITORING WELLS AT THE \\ U.S. DEPARTMENT OF ENERGY Y-12 NATIONAL SECURITY COMPLEX, OAK RIDGE, TENNESSEE Revision 2}

September 2013

\section{Prepared by}

ELVADO ENVIRONMENTAL LLC

Under Subcontract No. 4300087609

for the

Environmental Compliance Department Environment, Safety, and Health Division Y-12 National Security Complex Oak Ridge, Tennessee 37831

Managed by

Babcock \& Wilcox Technical Services Y-12, LLC for the U.S. DEPARTMENT OF ENERGY under contract No. DE-AC05-00OR22800 


\section{CONTENTS}

$\underline{\text { Section }} \quad$ Page

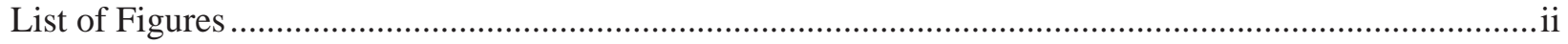

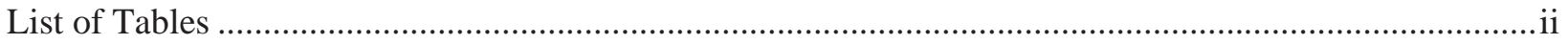

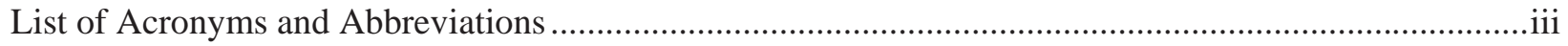

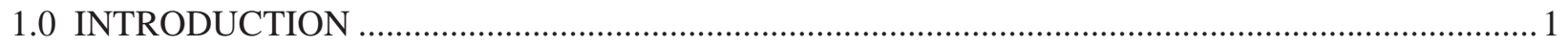

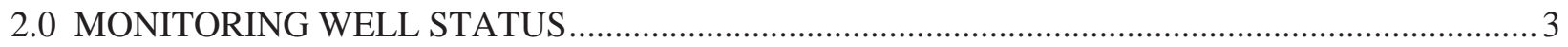

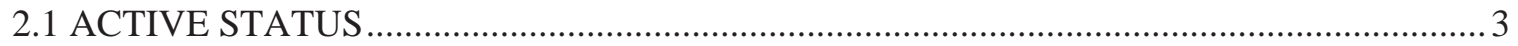

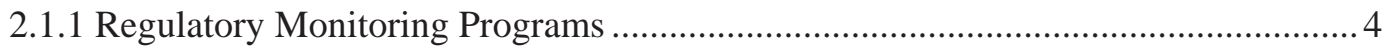

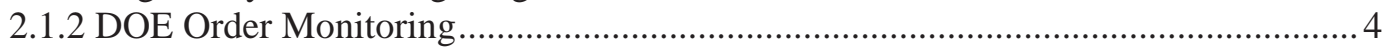

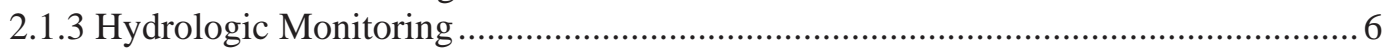

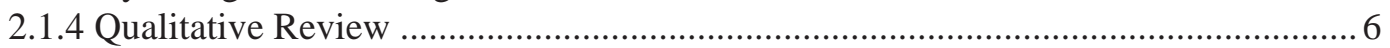

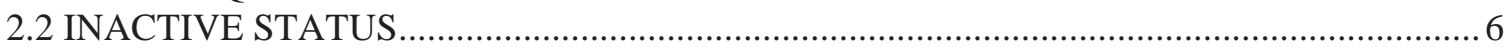

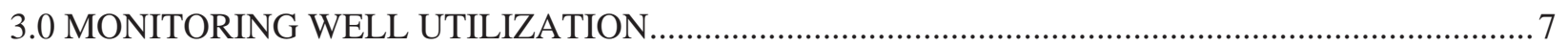

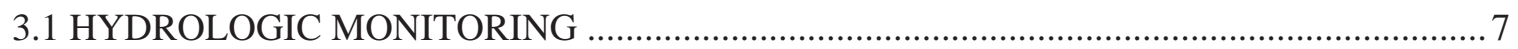

3.2 GROUNDWATER QUALITY SAMPLING …........................................................... 7

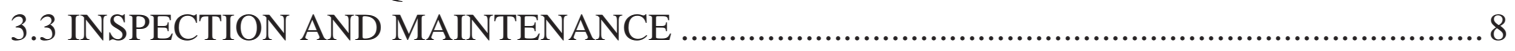

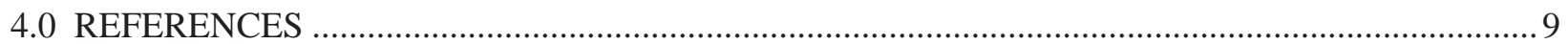

APPENDIX A: FIGURES

APPENDIX B: TABLES

APPENDIX C: ADDENDA 


\section{List of Figures}

Figure $\quad$ Page

A.1 Hydrogeologic regimes at the Y-12 National Security Complex .................................................. A-1

A.2 Process used to designate the status of groundwater monitoring wells at the Y-12 National Security Complex

A.3 Locations of groundwater monitoring wells in the Bear Creek Hydrogeologic Regime that are granted active status under the Y-12 Groundwater Protection Program

A.4 Locations of groundwater monitoring wells in the Upper East Fork Poplar Creek Hydrogeologic Regime that are granted active status under the Y-12 Groundwater Protection Program

A.5 Locations of groundwater monitoring wells in the Chestnut Ridge Hydrogeologic Regime that are granted active status under the Y-12 Groundwater Protection Program

\section{List of Tables}

Table

B.1 Groundwater monitoring wells that are granted active status under the Y-12 Groundwater Protection Program

B.2 Groundwater monitoring wells that are granted inactive status under the Y-12 Groundwater Protection Program 


\section{List of Acronyms and Abbreviations}

B\&W Y-12
Bear Creek Regime
BCV
BWXT
calendar year
CERCLA
Chestnut Ridge Regime
COC
DOE
DQOs
East Fork Regime
GWMR
GWPP
MAROS
ORR
PCP
RCRA
SAP
SPM
SWDF
Y-12

Babcock \& Wilcox Technical Services Y-12, LLC

Bear Creek Hydrogeologic Regime

Bear Creek Valley

BWXT Y-12, L.L.C.

CY

Comprehensive Environmental Response, Compensation, and Liability Act Chestnut Ridge Hydrogeologic Regime

contaminant(s) of concern

U.S. Department of Energy

data quality objectives

Upper East Fork Poplar Creek Hydrogeologic Regime

Groundwater Monitoring Report

Groundwater Protection Program

Monitoring and Remediation Optimization System

Oak Ridge Reservation

post-closure permit

Resource Conservation and Recovery Act

sampling and analysis plan

selective parameter monitoring

Solid Waste Disposal Facility

Y-12 National Security Complex 


\subsection{INTRODUCTION}

This document is the monitoring optimization plan for groundwater monitoring wells associated with the U.S. Department of Energy (DOE) Y-12 National Security Complex (Y-12) in Oak Ridge, Tennessee (Figure A.1). The plan describes the technical approach that is implemented under the Y-12 Groundwater Protection Program (GWPP) to focus available resources on the monitoring wells at Y-12 that provide the most useful hydrologic and groundwater quality monitoring data. The technical approach is based on the GWPP status designation for each well (Section 2.0). Under this approach, wells granted "active" status are used by the GWPP for hydrologic monitoring and/or groundwater quality sampling (Section 3.0), whereas wells granted "inactive" status are not used for either purpose. The status designation also defines the frequency at which the GWPP will inspect applicable wells, the scope of these well inspections, and extent of any maintenance actions initiated by the GWPP (Section 3.0). Details regarding the ancillary activities associated with implementation of this plan (e.g., well inspection) are deferred to the referenced GWPP plans (Section 4.0).

This plan applies to groundwater wells associated with Y-12 and related waste management areas and facilities located within three hydrogeologic regimes (Figure A.1): the Bear Creek Hydrogeologic Regime (Bear Creek Regime), the Upper East Fork Poplar Creek Hydrogeologic Regime (East Fork Regime), and the Chestnut Ridge Hydrogeologic Regime (Chestnut Ridge Regime). The Bear Creek Regime encompasses a section of Bear Creek Valley (BCV) immediately west of Y-12. The East Fork Regime encompasses most of the Y-12 process, operations, and support facilities in BCV. For this plan, the East Fork Regime includes a section of Union Valley east of the DOE Oak Ridge Reservation (ORR) boundary along Scarboro Road that is located hydraulically downgradient (along strike) from Y-12. The Chestnut Ridge Regime encompasses a section of Chestnut Ridge directly south of Y-12 that is bound on the west by a surface drainage feature (Dunaway Branch) and on the east by Scarboro Road. For this plan, the Chestnut Ridge Regime includes an area known as the South Campus Facility that is located west of Scarboro Road and south of Bethel Valley Road. The GWPP maintains an extensive database of construction details and related information for the monitoring wells in each hydrogeologic regime (including wells that have been destroyed or intentionally plugged and abandoned); the most recent hardcopy version of the database was issued in February 2003 (BWXT Y-12, L.L.C. [BWXT] 2003).

This plan does not apply to temporary piezometers or other specialized groundwater monitoring/sampling devices that have been or may be installed for research purposes, hydrologic tests, pilot studies, or short-term investigations. Additionally, this document does not apply to 141 groundwater monitoring wells located in western BCV that were formerly maintained by the GWPP before organizational stewardship responsibility was relinquished in February 2006.

This plan will be reviewed and updated every three years as specified in the Groundwater Protection Program Management Plan for the U.S. Department of Energy Y-12 National Security Complex, Oak Ridge, Tennessee (Babcock \& Wilcox Technical Services Y-12, LLC [B\&W Y-12] 2013a). Between scheduled updates, addenda issued by the GWPP Manager (or authorized designee) will document any substantive changes or modifications to the plan, including changes in the GWPP status designation for each monitoring well identified in the plan (see sample addendum in Appendix C). The addenda, numbered in consecutive ascending order, will be forwarded to all personnel included on the distribution list for this plan. The addenda are inserted in Appendix $\mathrm{C}$ pending the next scheduled update of the plan, which will incorporate the information included in the addenda. 


\subsection{MONITORING WELL STATUS}

For this plan, the existing groundwater monitoring wells at Y-12 are assigned active status (Table B.1) or inactive status (Table B.2) in accordance with the decision process illustrated on Figure A.2. Although the wells granted either status may be suitable for hydrologic monitoring and groundwater sampling, only wells granted active status will be used for either purpose by the GWPP.

The wells in each hydrogeologic regime that are granted active or inactive status under the GWPP reflect decisions made in response to the findings of an independent assessment of the GWPP that was completed in December 2005 (BWXT 2005) and a subsequent supplemental assessment completed in January 2009 (B\&W Y-12 2009). Both assessments, hereafter referenced as the baseline GWPP assessment and the supplemental GWPP assessment, respectively, included quantitative evaluations performed using Monitoring and Remediation Optimization System (MAROS) proprietary computer software. Only data that meet GWPP data quality objectives (DQOs) were used as MAROS input, with sampling results obtained during January 1995 - December 2004 evaluated under the baseline GWPP assessment, and sampling results obtained during January 1986 - December 2007 evaluated under the supplemental GWPP assessment. Quantitative evaluations performed by the MAROS software included temporal trend analyses (linear regression) and non-parametric trend analyses (Mann-Kendall) for each applicable contaminant of concern (COC) in the groundwater at each well. Also, for each COC, the MAROS software performed spatial analyses using a weighted "area-of-influence" approach (implemented using Delaunay triangulation) to determine the relative value (significance) of data generated by each well. For each applicable well, the results of these MAROS-based "well sufficiency" and "well redundancy" evaluations from the baseline and supplemental assessments of the GWPP were factored into the designation of active or inactive well status.

The designated status of each well will not change unless warranted by future circumstances and approved by the GWPP Manager. For example, a well that currently is granted inactive status may be used to replace a nearby well granted active status that has been irreparably damaged or destroyed. When a change in the status of a well is warranted, the GWPP Manager (or authorized designee) will issue an addendum to this plan that identifies the well and the reason(s) for the change in status.

\subsection{ACTIVE STATUS}

As detailed in the following respective subsections, active status under the GWPP is granted to a total of 362 wells at Y-12 that address the programmatic purposes listed below (Table B.1):

- 135 wells designated for use in one or more regulatory monitoring programs;

- 152 wells that specifically address site-wide groundwater monitoring requirements and objectives of DOE Order 436.1, Departmental Sustainability, and DOE Order 458.1, Radiation Protection of the Public and the Environment, which hereafter are referenced collectively as DOE Order Monitoring;

- 227 wells used to monitor groundwater surface elevations (hydrologic monitoring).

Note that approximately $40 \%$ of the wells granted active status (143 wells) serve multiple programmatic purposes (Table B.1), including 97 wells used for regulatory monitoring programs, 72 wells used for DOE Order Monitoring, and 124 wells used for hydrologic monitoring. The wells granted active status include 137 wells located in the Bear Creek Regime (Figure A.3), 137 wells located in the East Fork Regime (Figure A.4), and 86 wells located in the Chestnut Ridge Regime (Figure A.5). 
Active status under the GWPP also will be granted to any newly installed well that meets the design and construction standards described in the Monitoring Well Installation Plan for the Department of Energy Y-12 Plant, Oak Ridge, Tennessee (Lockheed Martin Energy Systems, Inc. 1997) and serves an ongoing regulatory monitoring program, or provides data suited to the technical purposes or programmatic objectives of the GWPP. New wells that do not meet these criteria will be granted inactive status. In either case, the GWPP Manager (or authorized designee) will issue an addendum to this plan to incorporate data for any new wells installed at Y-12.

\subsubsection{Regulatory Monitoring Programs}

Active status is granted to each groundwater monitoring well that is identified in the current respective Resource Conservation and Recovery Act (RCRA) post-closure permit (PCP) for the Bear Creek Regime, East Fork Regime, and Chestnut Ridge Regime. Each PCP defines the requirements for RCRA post-closure groundwater monitoring at the specified sites in the corresponding hydrogeologic regime. Collectively, the PCPs designate a total of 61 wells for RCRA post-closure detection monitoring and RCRA post-closure corrective action monitoring (Table B.1), including 25 wells located in the Bear Creek Regime, nine wells located in the East Fork Regime, and 27 wells located in the Chestnut Ridge Regime.

Active status is granted to each groundwater monitoring well that is specified in a Comprehensive Environmental Response, Liability, and Compensation Act (CERCLA) interim/final record of decision or the related decision document(s) for applicable facilities at Y-12. A total of 77 wells at Y-12 are monitored specifically for CERCLA-related groundwater monitoring purposes (Table B.1), including 27 wells located in the Bear Creek Regime, 37 wells located in the East Fork Regime, and 13 wells located in the Chestnut Ridge Regime. Twelve of these wells (four wells in each regime) also are listed in the respective PCPs (Table B.1). Note that the CERCLA wells located in the Bear Creek Regime include those used for groundwater quality monitoring at the Environmental Management Waste Management Facility.

Active status is granted to the 13 wells designated for SWDF detection monitoring at three nonhazardous solid waste landfills located in the Chestnut Ridge Regime (Table B.1): Industrial Landfill II, Industrial Landfill V, and Construction/Demolition Landfill VII. Active status also is granted to six wells designated for SWDF Assessment Monitoring Phase 3 at Industrial Landfill IV, including a downgradient "plume boundary well” located at the United Nuclear Corporation Site, which is an inactive CERCLA-regulated facility.

Ongoing RCRA-, CERCLA-, and SWDF-related groundwater sampling and analysis activities in each hydrogeologic regime at Y-12 are not implemented under the GWPP. Nevertheless, all the monitoring programs employ similar or technically equivalent groundwater sampling methods and laboratory analytical procedures. Consequently, the field and laboratory data obtained for the regulatory monitoring programs meet the DQOs of the GWPP, as defined in the most recent version of the $Y-12$ Groundwater Protection Program Data Management Plan (B\&W Y-12 2012), and are suitable for the purposes of DOE Order Monitoring.

\subsubsection{DOE Order Monitoring}

Active status is granted to each well at Y-12 that serves the following objectives and requirements specified by DOE Order 436.1 and 458.1 for site-wide monitoring of groundwater that has been or could be impacted by facility operations at Y-12:

- determine and document baseline conditions of groundwater quality and quantity; 
- demonstrate compliance with and implementation of all applicable state and federal regulations and DOE orders;

- ensure early detection of groundwater pollution or contamination from an operating facility or practice and provide an early warning to trigger appropriate response actions to unplanned releases of contaminants to the subsurface;

- identify existing and potential groundwater contamination sources and to maintain surveillance of these sources;

- evaluate groundwater quality in areas where contaminants have the potential to migrate off-site;

- meet long-term objectives for monitoring in areas where wastes and other subsurface contaminants will remain after all active site operations have ceased; and

- support decisions concerning land-use practices and the management of groundwater resources.

To achieve DOE Order Monitoring objectives, the GWPP performs hydrologic and groundwater quality monitoring in conjunction with concurrent RCRA, CERCLA, and SWDF monitoring performed by other organizations. Under the GWPP, groundwater quality monitoring is performed for surveillance monitoring purposes in areas of known, suspected, or potential sources of groundwater contamination at Y-12 and for perimeter/exit pathway monitoring purposes at site boundary locations and in the primary pathways for groundwater transport of mobile contaminants. Associated groundwater sampling and analysis activities are performed in accordance with standardized GWPP monitoring protocols described and/or referenced in the annual Sampling and Analysis Plan (SAP) issued by the GWPP for each calendar year (CY). Data (field measurements and analytical results) obtained for DOE Order Monitoring obtained during each CY are presented and evaluated in a Groundwater Monitoring Report (GWMR) issued annually by the GWPP.

Groundwater sampling and analysis activities performed by the GWPP for surveillance monitoring purposes are focused in areas of known, suspected, or potential sources of groundwater contamination at Y-12 that otherwise are not addressed under the ongoing RCRA, CERCLA, and SWDF monitoring programs, and include groundwater sampling and analysis activities associated with special hydrogeologic studies implemented by the GWPP. A total of 151 wells are designated for surveillance monitoring purposes, including 53 of the active status wells in the Bear Creek Regime, 86 of the active status wells in the East Fork Regime, and 12 of the active status wells in the Chestnut Ridge Regime (Table B.1). The number of wells sampled for surveillance monitoring purposes changes from year to year, depending on sampling frequency optimization and funding levels. The number of wells monitored by the GWPP varies between hydrogeologic regimes at Y-12, depending on the extent of monitoring coverage provided by the RCRA, CERCLA, and SWDF monitoring programs.

Groundwater sampling and analysis performed by the GWPP for perimeter/exit pathway monitoring purposes involves a network of 11 monitoring wells located in an area along the ORR property boundary at the eastern end of Y-12 between Upper East Fork Poplar Creek and Scarboro Road (Figure A.4). The designated perimeter monitoring wells in the East Fork Regime include several wells that are located along a strikenormal transect across the Maynardville Limestone), which provides the principal pathways for mobile groundwater contaminants to migrate eastward beyond the ORR property boundary. Additional data from several regulatory wells and from surface water and spring monitoring locations are used to meet perimeter/exit pathway monitoring requirements. In the Bear Creek Regime, the designated perimeter monitoring wells are RCRA wells located approximately 6,500 ft southwest of the BCBG along a strikenormal transect across the Maynardville Limestone (Figure A.3), which provides the principal pathways for mobile groundwater contaminants to migrate westward beyond the current extent of contamination in BCV. 


\subsubsection{Hydrologic Monitoring}

Active status is granted to each groundwater monitoring well that is part of the respective regime-wide network of wells used for monitoring groundwater surface elevations in the Bear Creek Regime, East Fork Regime, and Chestnut Ridge Regime. Section 3.1 provides details regarding the hydrologic monitoring wells in each regime. Using fixed networks of hydrologic monitoring wells in each regime ensures that the GWPP obtains adequate, equivalent, consistent, and representative groundwater elevation data.

\subsubsection{Qualitative Review}

Regardless of the other applicable criteria, active status may be granted to any well at Y-12 that, based on the objective professional judgment of the GWPP Manager, is considered suitable for the technical purposes and/or programmatic objectives of the GWPP.

\subsection{INACTIVE STATUS}

Based on the criteria listed below, inactive status under the GWPP currently is granted to 189 groundwater monitoring wells at Y-12, including 99 wells in the Bear Creek Regime, 65 wells in the East Fork Regime, and 25 wells in the Chestnut Ridge Regime (Table B.2).

- Wells for which the design and construction details are not known or do not meet GWPP technical standards, and wells that do not meet other GWPP requirements (e.g., all-weather access).

- Wells for which groundwater quality and hydrologic monitoring data are not available or are no longer needed to serve the technical or programmatic purposes of the GWPP.

- Wells for which the baseline (BWXT 2005) or the supplemental (B\&W Y-12 2009) assessments of the GWPP recommend discontinued groundwater quality monitoring under the GWPP (Figure A.2). The assessment criteria included quantitative well redundancy evaluation to differentiate wells that provide less significant data from one or more neighboring wells and, therefore, do not warrant continued groundwater sampling (unless specifically required under a regulatory-driven monitoring program). Based on the professional judgment of the GWPP Manager, discontinued groundwater sampling was accepted as recommended for all but 11 of the 151 wells specified in the baseline assessment (122 wells) and supplemental assessment (29 wells).

As noted previously, a well currently granted inactive status under the GWPP may be re-assigned active status in response to programmatic or technical changes. Similarly, active status will be re-assigned to any well currently granted inactive status that becomes incorporated into ongoing RCRA, CERCLA, or SWDF monitoring programs at Y-12. 


\subsection{MONITORING WELL UTILIZATION}

As described in the following subsections, each groundwater monitoring well at Y-12 that is granted active status under the GWPP is generally suitable for hydrologic monitoring and/or groundwater quality sampling. To ensure their continued use for either purpose, the wells will be appropriately inspected and maintained.

\subsection{HYDROLOGIC MONITORING}

A total of 226 wells at Y-12 that are granted active status under the GWPP are designated for hydrologic monitoring (Table B.1), including 85 wells in the Bear Creek Regime, 64 wells in the East Fork Regime, and 77 wells in the Chestnut Ridge Regime. The respective network of hydrologic monitoring wells in each regime provides the geographic coverage needed to determine regime-wide groundwater surface elevations, evaluate localized groundwater flow patterns, and calculate representative hydraulic gradients.

The elevation of the groundwater surface throughout the Bear Creek Regime, East Fork Regime, and Chestnut Ridge Regime will be determined at least annually based on the depth-to-water measurements recorded for the hydrologic monitoring wells in each regime. The depth to water in each well will be measured in accordance with the most recent approved version of the applicable GWPP procedure or one that is functionally equivalent. Annual depth-to-water measurements will be performed during alternating wet (winter and spring) and dry (summer and fall) seasonal flow conditions. To ensure the most contemporaneous regimewide data, measurements of the depth to water in all of the hydrologic monitoring wells in each regime will be completed in the shortest time practical.

\subsection{GROUNDWATER QUALITY SAMPLING}

The GWPP defines the groundwater quality sampling requirements (sampling frequency, sampling method, field measurements, and laboratory analytes) for each well granted active status under the GWPP, excluding wells that serve RCRA, CERCLA, or SWDF monitoring programs, which have regulatory- and permit-driven (and technically equivalent) sampling protocols. The sampling frequency only applies to sampling performed under the GWPP and does not replace or supersede any regulatory and/or permit-driven sampling frequency specified for applicable wells granted active status (e.g., wells designated for RCRA Monitoring).

The groundwater sampling frequency for each well used for DOE Order Monitoring at Y-12 is based on results of MAROS-based quantitative evaluations performed under the supplemental assessment of the GWPP and the professional judgment of the GWPP Manager (Table B.1). Output from the MAROS evaluations specified one of the following recommended sampling frequencies for each well: semiannual, annual, biennial, every five years, or eliminate (discontinue sampling). The GWPP Manager assigned the CY (even or odd) sampling schedule for wells with a biennial or five-year sampling frequency (Table B.1). The annual SAP issued by the GWPP shows the required sampling frequency for all applicable wells scheduled for sampling during the CY.

The annual GWMR issued by the GWPP presents an evaluation of the groundwater monitoring results obtained each CY. Based on the results of the annual evaluations, the GWMR may contain recommendations to alter the sampling frequency for applicable wells. Any such recommended changes are evaluated by the GWPP Manager and, if approved, are reflected in the subsequent annual SAP issued by the GWPP and included as an addendum to this plan (Appendix C). 
Only unfiltered groundwater quality samples are collected by the GWPP; filtered samples are obtained only if specifically requested by the GWPP Manager (or authorized designee). The use of low impact sampling methods (e.g., low-flow, minimal drawdown) typically yields non-turbid groundwater samples and therefore eliminates the need for routine filtered sample results. All sampling and related field activities (e.g., depth-towater measurements) are performed in accordance with the methods described in the GWPP procedures, or functionally equivalent procedures used by other organizations responsible for implementation of the regulatory monitoring programs at Y-12.

Historically, all groundwater samples collected by the GWPP were analyzed for a comprehensive suite of inorganic, organic, and radiological analytes referred to as the Standard Administrative Parameter Group. Beginning in January 2009, selective parameter monitoring (SPM) for a reduced list of analytes was adopted for groundwater samples from a subset of monitoring wells for which available data clearly demonstrate that the selected parameters encompass all COC and provide sufficient data for GWPP purposes. Groundwater samples from wells selected for SPM periodically may be analyzed for the full Standard Administrative Parameter Group to verify consistency with historical data or to meet programmatic requirements of the GWPP.

\subsection{INSPECTION AND MAINTENANCE}

Groundwater monitoring wells at Y-12 are regularly inspected and actively maintained to ensure that they continue to yield representative hydrologic and groundwater quality monitoring data. The active or inactive status designation for each well determines the frequency at which the GWPP will inspect the applicable wells, the scope of these inspections, and the extent of maintenance response actions. Inspection and maintenance activities will be performed in accordance with the most recent version of the Monitoring Well Inspection and Maintenance Plan, Y-12 Plant, Oak Ridge, Tennessee (B\&W Y-12 2013c), which applies only to the wells for which B\&W Y-12 assumes organizational responsibility under the GWPP. Other organizations retain responsibility for the wells that are used for RCRA-, CERCLA-, and SWDF-related groundwater monitoring, with respective inspection and maintenance requirements defined and/or referenced in the governing regulatory documents (see Section 2.1.1).

Wells granted active status under the GWPP will be inspected annually. During each inspection of each well, the security status (locked or unlocked well cap) will be verified and the applicable above-ground components (identification tag, cap, lock hasp, lock, concrete pad, and protective posts) will be assessed for visible damage, deterioration, and functionality. All-weather access to each well also will be evaluated during the annual inspection. Every three years, as a qualitative check on down-hole conditions in each well, the total depth to the bottom of the well will be measured and compared to the Reference Tag Depth for the well (B\&W Y-12 2013b). Based on the outcome of each inspection, the GWPP Manager will initiate the necessary and appropriate maintenance actions needed to ensure the access, security, physical condition, and performance of the applicable well(s).

Wells granted inactive status under the GWPP will be inspected once every three years (B\&W Y-12 2013c). During each inspection, the security status of each well will be verified; the applicable above-ground components of each well will be assessed for visible damage, deterioration, and functionality; and the total depth to the bottom of each well will be measured and compared to the Reference Tag Depth for the well (B\&W Y-12 2013b). Based on the outcome of each inspection, the GWPP Manager will initiate only those maintenance actions needed to ensure the security and identification of each well, such as replacement of inoperable well locks and identification tags. Also, damaged wells that may represent an uncontrolled conduit from the surface to the subsurface will be repaired or plugged and abandoned as quickly as possible. 


\subsection{REFERENCES}

Babcock \& Wilcox Technical Services Y-12, LLC (B\&W Y-12). 2009. Supplemental Assessment of the Y12 Groundwater Protection Program Using Monitoring and Remediation Optimization System Software. Prepared by Elvado Environmental LLC and GSI Environmental, Inc. (Y/TS-2118).

B\&W Y-12. 2012. Y-12 Groundwater Protection Program Data Management Plan. Prepared by the Environment, Safety, and Health Division and the Information Technology Organization (Y/TS2007/R4).

B\&W Y-12. 2013a. Groundwater Protection Program Management Plan for the U.S. Department of Energy Y-12 National Security Complex, Oak Ridge, Tennessee. Prepared by Elvado Environmental LLC. (Y/SUB/01-006512/2/R3).

B\&W Y-12. 2013b. Y-12 Groundwater Protection Program CY 2012 Triennial Report of the Monitoring Well Inspection and Maintenance Program, Y-12 National Security Complex, Oak Ridge, Tennessee. Prepared by the Y-12 Environment, Safety, and Health Division (Y/TS-2352).

B\&W Y-12. 2013c. Monitoring Well Inspection and Maintenance Plan. Prepared by the Y-12 Environment, Safety, and Health Division (Y/TS-1215/R4).

BWXT Y-12 L.L.C. 2003. Updated Subsurface Data Base for Bear Creek Valley, Chestnut Ridge, and Parts of Bethel Valley on the U.S. Department of Energy Oak Ridge Reservation. Prepared by the Y-12 Environment, Safety, and Health Division (Y/TS-881/R5).

BWXT Y-12 L.L.C. 2005. Assessment of the Groundwater Protection Program, Y-12 National Security Complex, Oak Ridge, Tennessee. Prepared by Groundwater Services, Inc. (Y/TS-1984)

Lockheed Martin Energy Systems, Inc. 1997. Monitoring Well Installation Plan for the Department of Energy Y-12 Plant, Oak Ridge, Tennessee. Prepared by Science Applications International Corporation (Y/SUB/00-KFX63/C/1). 
APPENDIX A

\section{FIGURES}




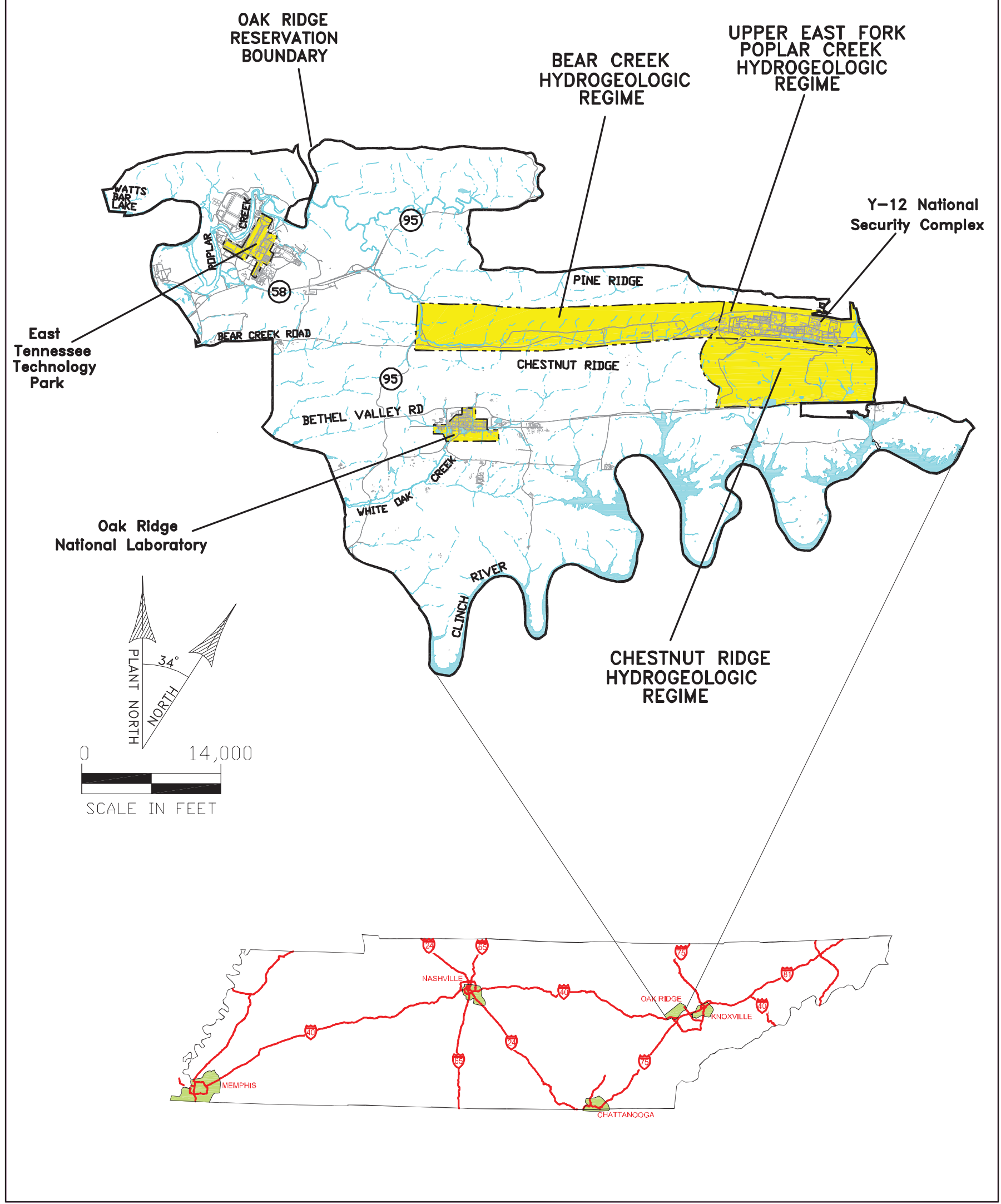

GWPP Fig1 $08 / 21 / 13$

Fig. A.1. Hydrogeologic regimes at the Y-12 National Security Complex. 


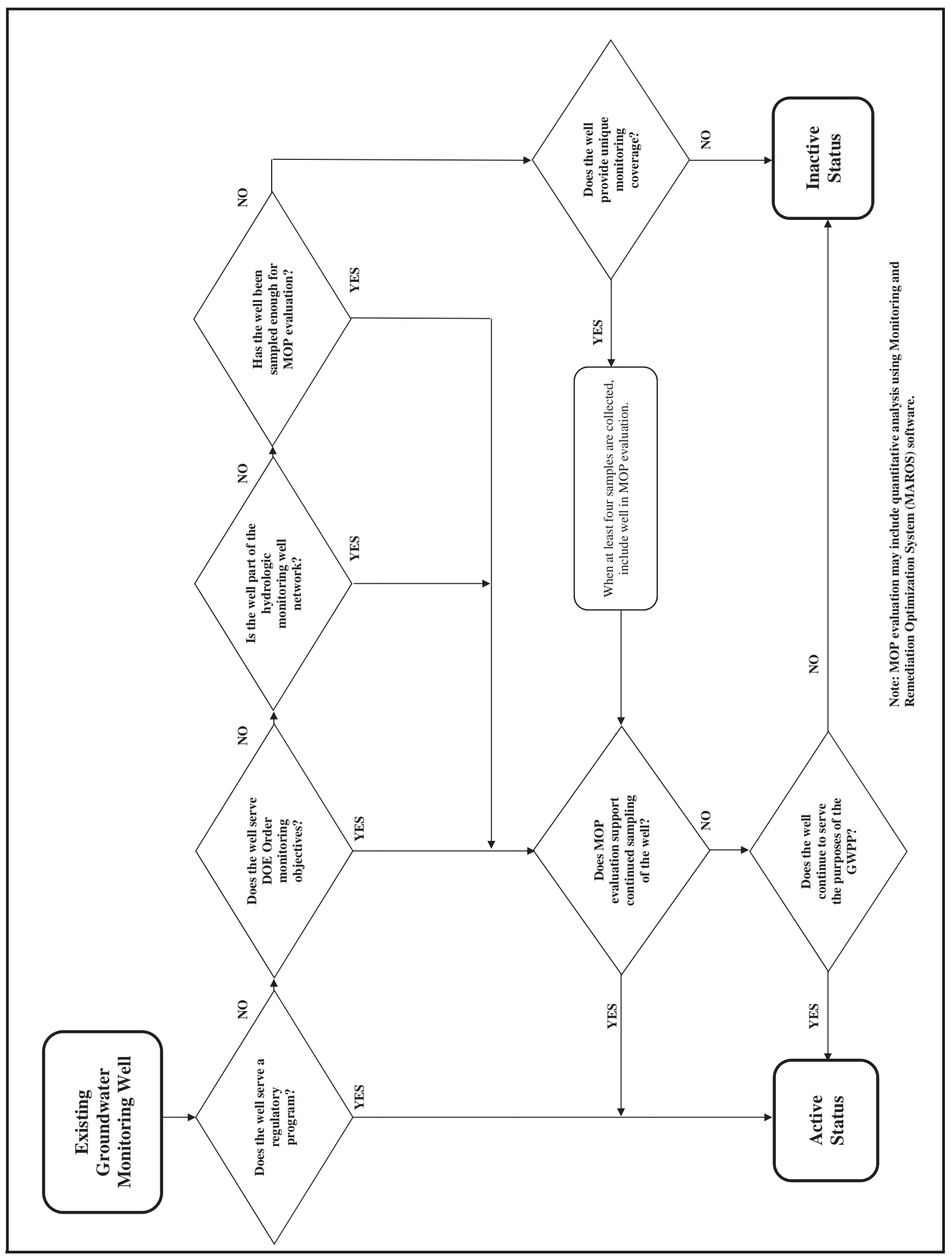

Fig. A.2. Process used to designate the status of groundwater monitoring wells at the Y-12 National Security Complex. 


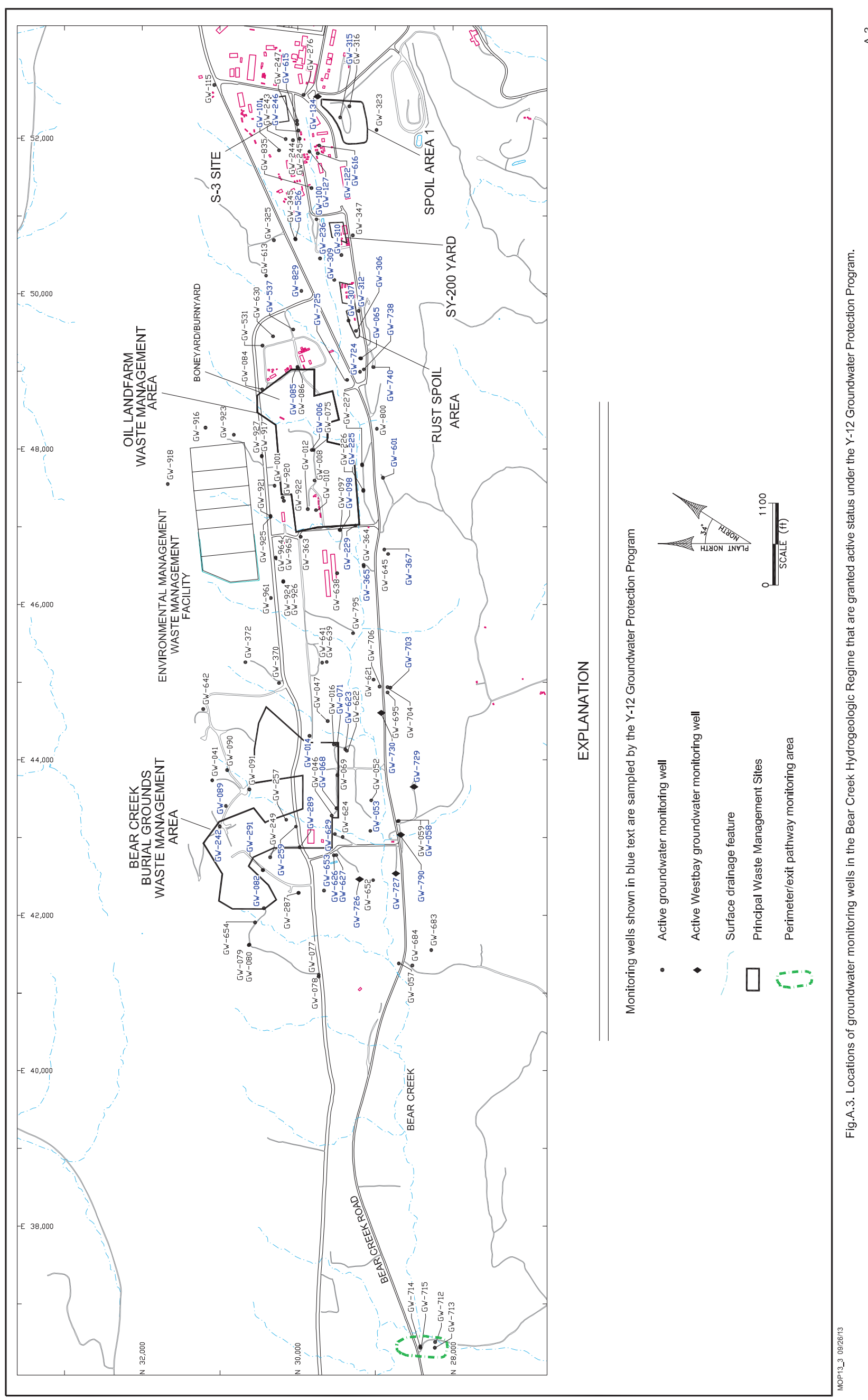



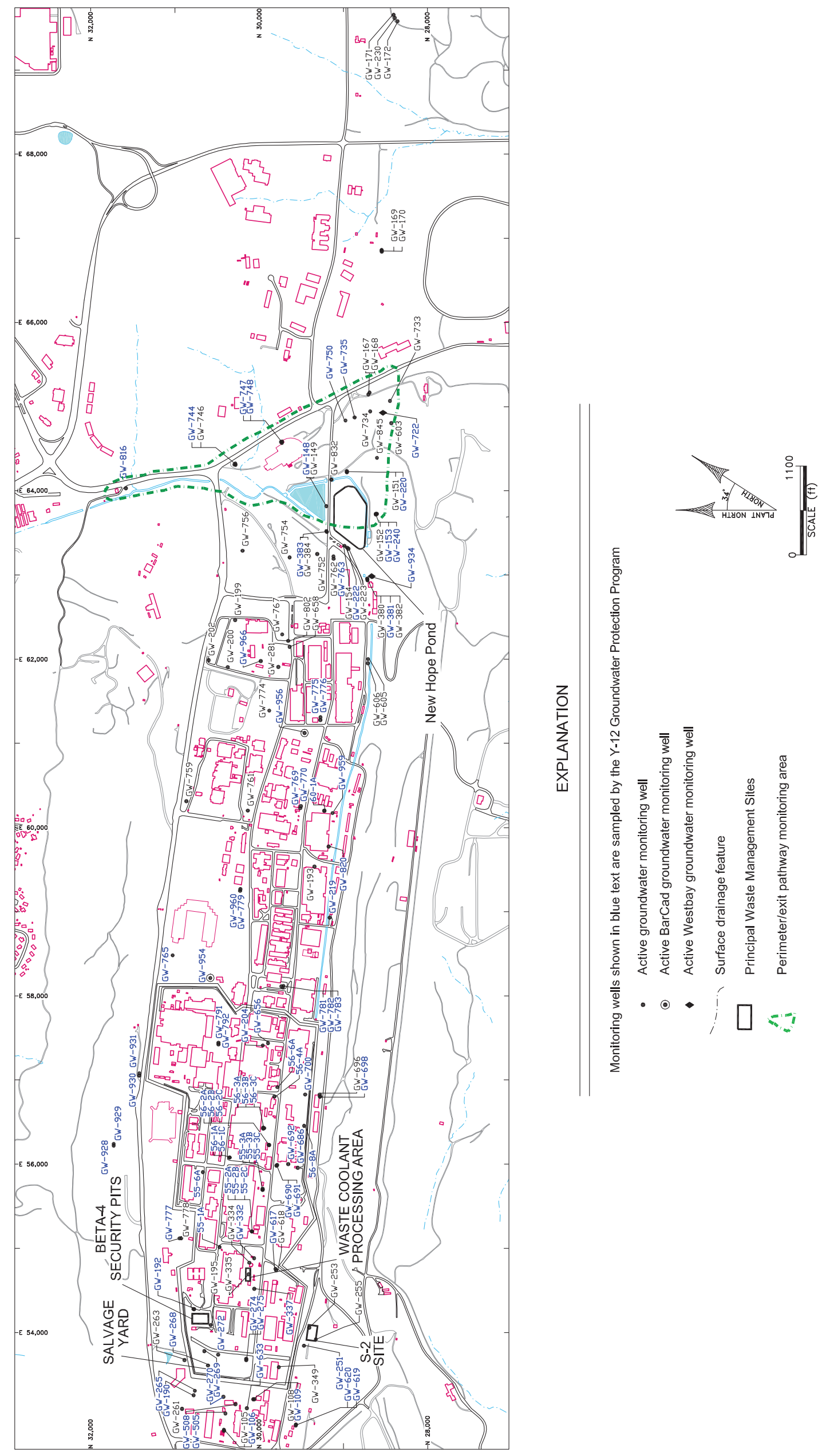

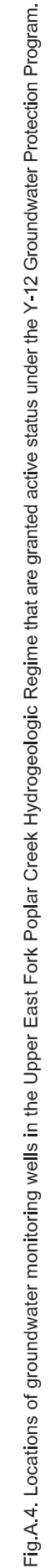

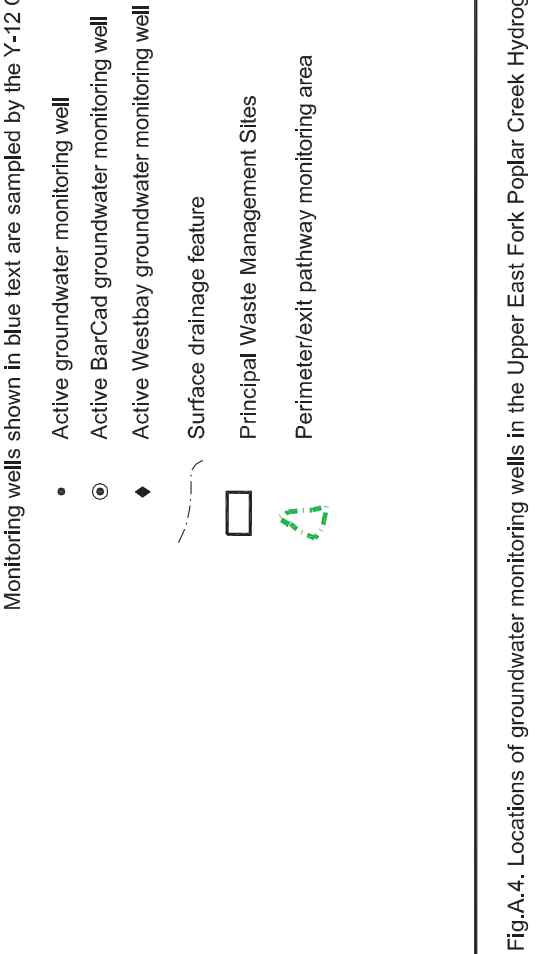



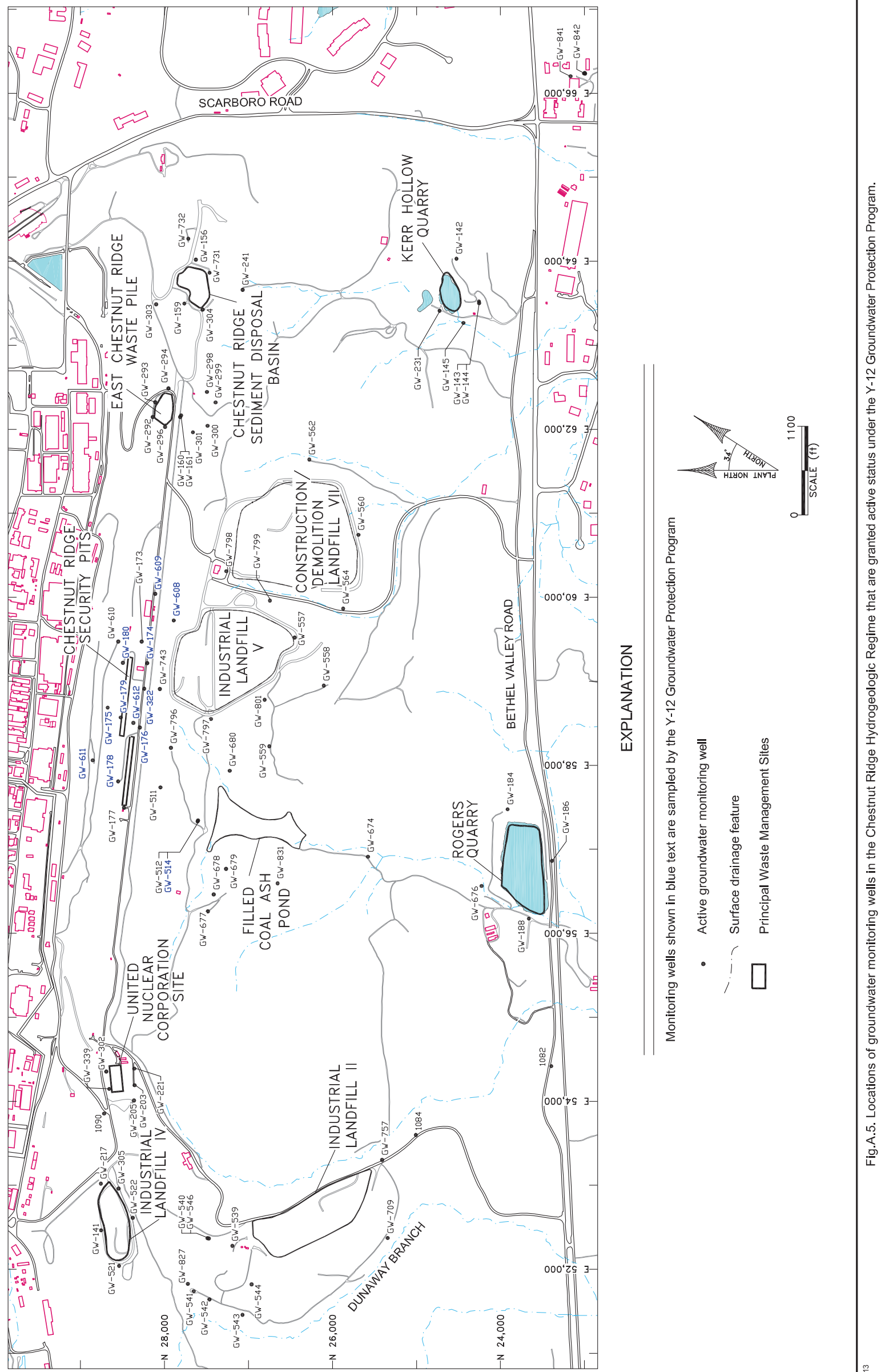
APPENDIX B

TABLES 
Table B.1 Groundwater monitoring wells that are granted active status under the Y-12 Groundwater Protection Program

\begin{tabular}{|c|c|c|c|c|c|c|c|}
\hline \multirow{3}{*}{\multicolumn{2}{|c|}{$\begin{array}{l}\text { Well Number and } \\
\text { Location }^{1}\end{array}$}} & \multicolumn{5}{|c|}{ Active Status Criteria $^{2}$} & \multirow{3}{*}{$\begin{array}{c}\text { GWPP } \\
\text { Sampling } \\
\text { Frequency }\end{array}$} \\
\hline & & \multicolumn{3}{|c|}{ Regulatory Monitoring } & \multirow{3}{*}{$\begin{array}{c}\begin{array}{c}\text { Hydrologic } \\
\text { Monitoring }\end{array} \\
\bullet \\
\end{array}$} & \multirow{2}{*}{$\begin{array}{l}\text { DOE Order } \\
\text { Monitoring } \\
\end{array}$} & \\
\hline & & \multirow{2}{*}{ RCRA } & \multirow{2}{*}{$\begin{array}{c}\text { CERCLA } \\
.\end{array}$} & \multirow{2}{*}{ SWDF } & & & \\
\hline 1082 & CR & & & & & . & . \\
\hline 1084 & $\mathrm{CR}$ & . & . & . & $\bullet$ & . & . \\
\hline 1090 & $\mathrm{CR}$ & . & $\bullet$ & . & $\bullet$ & . & . \\
\hline $55-1 \mathrm{~A}$ & $\mathrm{EF}$ & . & . & . & $\bullet$ & $\bullet$ & 5 Year $(2013)$ \\
\hline $55-2 \mathrm{~A}$ & EF & . & . & . & . & $\bullet$ & Biennial (Odd) \\
\hline $55-2 \mathrm{~B}$ & EF & . & . & . & . & $\bullet$ & Annual \\
\hline $55-2 \mathrm{C}$ & $\mathrm{EF}$ & . & . & . & . & $\bullet$ & Annual \\
\hline $55-3 \mathrm{~A}$ & $\mathrm{EF}$ & . & . & . & $\bullet$ & $\bullet$ & Annual \\
\hline $55-3 \mathrm{~B}$ & EF & . & . & . & . & $\bullet$ & Annual \\
\hline $55-3 \mathrm{C}$ & $\mathrm{EF}$ & . & . & . & . & $\bullet$ & Annual \\
\hline $55-6 \mathrm{~A}$ & $\mathrm{EF}$ & . & . & . & $\bullet$ & $\bullet$ & 5 Year (2013) \\
\hline $56-1 \mathrm{~A}$ & EF & . & . & . & $\bullet$ & $\bullet$ & Annual \\
\hline $56-1 \mathrm{C}$ & $\mathrm{EF}$ & . & . & . & . & $\bullet$ & Annual \\
\hline $56-2 \mathrm{~A}$ & $\mathrm{EF}$ & . & . & . & $\bullet$ & $\bullet$ & Annual \\
\hline $56-2 \mathrm{~B}$ & $\mathrm{EF}$ & . & . & . & . & $\bullet$ & Annual \\
\hline $56-2 \mathrm{C}$ & $\mathrm{EF}$ & . & . & . & . & $\bullet$ & Annual \\
\hline $56-3 \mathrm{~A}$ & $\mathrm{EF}$ & . & . & . & . & $\bullet$ & Annual \\
\hline $56-3 \mathrm{~B}$ & EF & . & . & . & . & $\bullet$ & Annual \\
\hline $56-3 \mathrm{C}$ & $\mathrm{EF}$ & . & . & . & . & $\bullet$ & Annual \\
\hline $56-4 \mathrm{~A}$ & $\mathrm{EF}$ & . & . & . & . & $\bullet$ & Annual \\
\hline $56-6 \mathrm{~A}$ & $\mathrm{EF}$ & . & . & . & . & $\bullet$ & Biennial (Even) \\
\hline $56-8 \mathrm{~A}$ & $\mathrm{EF}$ & . & . & . & $\bullet$ & $\bullet$ & Biennial (Even) \\
\hline $60-1 \mathrm{~A}$ & $\mathrm{EF}$ & . & . & . & $\bullet$ & $\bullet$ & Biennial (Even) \\
\hline GW-001 & $\mathrm{BC}$ & . & . & . & $\bullet$ & . & . \\
\hline GW-006 & $\mathrm{BC}$ & . & . & . & . & $\bullet$ & Biennial (Even) \\
\hline GW-008 & $\mathrm{BC}$ & $\bullet$ & . & . & $\bullet$ & . & . \\
\hline GW-010 & $\mathrm{BC}$ & $\bullet$ & . & . & $\bullet$ & . & . \\
\hline GW-012 & $\mathrm{BC}$ & $\bullet$ & . & . & $\bullet$ & . & . \\
\hline GW-014 & $\mathrm{BC}$ & $\bullet$ & . & . & $\bullet$ & $\bullet$ & Annual \\
\hline GW-016 & $\mathrm{BC}$ & . & . & . & $\bullet$ & . & . \\
\hline GW-041 & $\mathrm{BC}$ & . & . & . & $\bullet$ & . & . \\
\hline GW-046 & $\mathrm{BC}$ & $\bullet$ & . & . & $\bullet$ & . & . \\
\hline GW-047 & $\mathrm{BC}$ & . & . & . & $\bullet$ & . & . \\
\hline GW-052 & $\mathrm{BC}$ & . & . & . & $\bullet$ & . & . \\
\hline GW-053 & $\mathrm{BC}$ & . & . & . & $\bullet$ & $\bullet$ & Biennial (Odd) \\
\hline GW-057 & $\mathrm{BC}$ & . & . & . & $\bullet$ &. &. \\
\hline GW-058 & $\mathrm{BC}$ & . & . & . & . & $\bullet$ & Biennial (Odd) \\
\hline GW-059 & $\mathrm{BC}$ & . & . & . & $\bullet$ & . & . \\
\hline GW-065 & $\mathrm{BC}$ & . & . & . & $\bullet$ & $\bullet$ & Biennial (Even) \\
\hline GW-068 & $\mathrm{BC}$ & . & . & . & . & $\bullet$ & Annual \\
\hline GW-069 & $\mathrm{BC}$ & $\bullet$ & . & . & $\bullet$ & 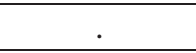 & . \\
\hline GW-071 & $\mathrm{BC}$ & $\bullet$ & . & . & . & $\bullet$ & Biennial (Odd) \\
\hline
\end{tabular}


Table B.1 (continued)

\begin{tabular}{|c|c|c|c|c|c|c|c|}
\hline \multirow{3}{*}{\multicolumn{2}{|c|}{$\begin{array}{l}\text { Well Number and } \\
\text { Location }^{1}\end{array}$}} & \multicolumn{5}{|c|}{ Active Status Criteria $^{2}$} & \multirow{4}{*}{$\begin{array}{c}\begin{array}{c}\text { GWPP } \\
\text { Sampling } \\
\text { Frequency }\end{array} \\
.\end{array}$} \\
\hline & & \multicolumn{3}{|c|}{ Regulatory Monitoring } & \multirow{3}{*}{$\begin{array}{c}\begin{array}{c}\text { Hydrologic } \\
\text { Monitoring }\end{array} \\
.\end{array}$} & \multirow{3}{*}{$\begin{array}{l}\text { DOE Order } \\
\text { Monitoring } \\
\end{array}$} & \\
\hline & & \multirow{2}{*}{$\frac{\text { RCRA }}{\bullet}$} & \multirow{2}{*}{$\begin{array}{c}\text { CERCLA } \\
\end{array}$} & \multirow{2}{*}{ SWDF } & & & \\
\hline GW-075 & $\mathrm{BC}$ & & & & & & \\
\hline GW-077 & $\mathrm{BC}$ & . & $\bullet$ & . & . & . &. \\
\hline GW-078 & $\mathrm{BC}$ & . & $\bullet$ & . & $\bullet$ & . & . \\
\hline GW-079 & $\mathrm{BC}$ & . & $\bullet$ & . & . & . & . \\
\hline GW-080 & $\mathrm{BC}$ & . & $\bullet$ & . & $\bullet$ & . & . \\
\hline GW-082 & $\mathrm{BC}$ & $\bullet$ & . & . & $\bullet$ & $\bullet$ & Annual \\
\hline GW-084 & $\mathrm{BC}$ & . & . & . & $\bullet$ & . & . \\
\hline GW-085 & $\mathrm{BC}$ & . & . & . & . & $\bullet$ & Annual \\
\hline GW-086 & $\mathrm{BC}$ & . & . & . & $\bullet$ & . & . \\
\hline GW-089 & $\mathrm{BC}$ & . & . & . & . & $\bullet$ & 5 Year (2013) \\
\hline GW-090 & $\mathrm{BC}$ & . & . & . & $\bullet$ & . & . \\
\hline GW-091 & $\mathrm{BC}$ & . & . & . & $\bullet$ & . & . \\
\hline GW-097 & $\mathrm{BC}$ & . & . & . & $\bullet$ & . & . \\
\hline GW-098 & $\mathrm{BC}$ & . & . & . & . & $\bullet$ & Annual \\
\hline GW-100 & $\mathrm{BC}$ & . & . & . & $\bullet$ & $\bullet$ & Annual \\
\hline GW-101 & $\mathrm{BC}$ & $\bullet$ & . & . & $\bullet$ & $\bullet$ & Annual \\
\hline GW-105 & $\mathrm{EF}$ & . & . & . & $\bullet$ & . &. \\
\hline GW-106 & $\mathrm{EF}$ & . & . & . & . & $\bullet$ & Biennial (Even) \\
\hline GW-108 & $\mathrm{EF}$ & $\bullet$ & . & . & $\bullet$ & . & . \\
\hline GW-109 & $\mathrm{EF}$ & $\bullet$ & . & . & . & $\bullet$ & Biennial (Even) \\
\hline GW-115 & $\mathrm{BC}$ & . & . & . & $\bullet$ & . & . \\
\hline GW-122 & $\mathrm{BC}$ & . & . & . & . & $\bullet$ & Biennial (Odd) \\
\hline GW-127 & $\mathrm{BC}$ & $\bullet$ & . & . & $\bullet$ & $\bullet$ & Biennial (Odd) \\
\hline GW-134 (10) & $\mathrm{BC}$ & . & . & . & . & $\bullet$ & TBD \\
\hline GW-141 & CR & . & . & $\bullet$ & $\bullet$ & . & . \\
\hline GW-142 & $\mathrm{CR}$ & . & . & . & $\bullet$ & . & . \\
\hline GW-143 & $\mathrm{CR}$ & - & $\bullet$ & . & . & . & . \\
\hline GW-144 & $\mathrm{CR}$ & - & $\bullet$ & . & $\bullet$ & . & . \\
\hline GW-145 & $\mathrm{CR}$ & - & $\bullet$ & . & $\bullet$ & . & . \\
\hline GW-148 & $\mathrm{EF}$ & . & . & . & $\bullet$ & $\bullet$ & Biennial (Even) \\
\hline GW-149 & $\mathrm{EF}$ & . & $\bullet$ & . & . & . & . \\
\hline GW-151 & $\mathrm{EF}$ & . & $\bullet$ & . & $\bullet$ & . & . \\
\hline GW-152 & $\mathrm{EF}$ & . & $\bullet$ & . & $\bullet$ & . & . \\
\hline GW-153 & $\mathrm{EF}$ & . & $\bullet$ & . & . & $\bullet$ & Annual \\
\hline GW-154 & $\mathrm{EF}$ & . & $\bullet$ & . & $\bullet$ & . & . \\
\hline GW-156 & CR & - & . & . & $\bullet$ & . & . \\
\hline GW-159 & $\mathrm{CR}$ & - & . & . & $\bullet$ & . & . \\
\hline GW-160 & $\mathrm{CR}$ & . & . & . & $\bullet$ & . & . \\
\hline GW-161 & $\mathrm{CR}$ & - & . & . & . & . & . \\
\hline GW-167 & $\mathrm{EF}$ & . & . & . & $\bullet$ & . & . \\
\hline GW-168 & $\mathrm{EF}$ & . & $\bullet$ & . & . & . & . \\
\hline GW-169 & $\mathrm{EF}$ & . & $\bullet$ & . & $\bullet$ & . & . \\
\hline GW-170 & $\mathrm{EF}$ & . & $\bullet$ & . & . & . & . \\
\hline
\end{tabular}


Table B.1 (continued)

\begin{tabular}{|c|c|c|c|c|c|c|c|}
\hline \multirow{3}{*}{\multicolumn{2}{|c|}{$\begin{array}{l}\text { Well Number and } \\
\text { Location }^{1}\end{array}$}} & \multicolumn{5}{|c|}{ Active Status Criteria $^{2}$} & \multirow{4}{*}{$\begin{array}{c}\begin{array}{c}\text { GWPP } \\
\text { Sampling } \\
\text { Frequency }\end{array} \\
.\end{array}$} \\
\hline & & \multicolumn{3}{|c|}{ Regulatory Monitoring } & \multirow{2}{*}{$\begin{array}{l}\text { Hydrologic } \\
\text { Monitoring }\end{array}$} & \multirow{2}{*}{$\begin{array}{l}\text { DOE Order } \\
\text { Monitoring }\end{array}$} & \\
\hline & & \multirow{2}{*}{ RCRA } & \multirow{2}{*}{$\begin{array}{c}\text { CERCLA } \\
\bullet\end{array}$} & \multirow{2}{*}{ SWDF } & & & \\
\hline GW-171 & $\mathrm{EF}$ & & & & . & . & \\
\hline GW-172 & $\mathrm{EF}$ & . & $\bullet$ & . & . & . & . \\
\hline GW-173 & $\mathrm{CR}$ & . & . & . & $\bullet$ & . & . \\
\hline GW-174 & $\mathrm{CR}$ & . & . & . & $\bullet$ & $\bullet$ & Biennial (Odd) \\
\hline GW-175 & $\mathrm{CR}$ & $\bullet$ & . & . & $\bullet$ & $\bullet$ & Biennial (Odd) \\
\hline GW-176 & $\mathrm{CR}$ & . & . & . & $\bullet$ & $\bullet$ & Biennial (Odd) \\
\hline GW-177 & CR & $\bullet$ & . & . & $\bullet$ & . & . \\
\hline GW-178 & $\mathrm{CR}$ & . & . & . & $\bullet$ & $\bullet$ & 5 Year (2013) \\
\hline GW-179 & $\mathrm{CR}$ & . & . & . & $\bullet$ & $\bullet$ & 5 Year (2017) \\
\hline GW-180 & CR & . & . & . & $\bullet$ & $\bullet$ & Biennial (Odd) \\
\hline GW-184 & $\mathrm{CR}$ & . & . & . & $\bullet$ & . & . \\
\hline GW-186 & CR & . & . & . & $\bullet$ & . & . \\
\hline GW-188 & $\mathrm{CR}$ & . & . & . & $\bullet$ & . & . \\
\hline GW-190 & EF & . & . & . & . & $\bullet$ & 5 Year (2013) \\
\hline GW-192 & $\mathrm{EF}$ & . & . & . & $\bullet$ & $\bullet$ & 5 Year (2013) \\
\hline GW-193 & $\mathrm{EF}$ & $\bullet$ & . & . & $\bullet$ & . & . \\
\hline GW-195 & $\mathrm{EF}$ & . & . & . & $\bullet$ & . & . \\
\hline GW-199 & $\mathrm{EF}$ & . & . & . & $\bullet$ & . & . \\
\hline GW-200 & $\mathrm{EF}$ & . & . & . & $\bullet$ & . & . \\
\hline GW-202 & $\mathrm{EF}$ & . &. & . & $\bullet$ & . & . \\
\hline GW-203 & CR & . & $\bullet$ & . & $\bullet$ & . & . \\
\hline GW-204 & $\mathrm{EF}$ & . & . & . & $\bullet$ & $\bullet$ & Annual \\
\hline GW-205 & CR & . & $\bullet$ & $\bullet$ & $\bullet$ & . & . \\
\hline GW-217 & $\mathrm{CR}$ & . & . & $\bullet$ & $\bullet$ & . & . \\
\hline GW-219 & $\mathrm{EF}$ &. & $\bullet$ & . & $\bullet$ & $\bullet$ & Biennial (Odd) \\
\hline GW-220 & $\mathrm{EF}$ & . & . & . & . & $\bullet$ & Semiannual \\
\hline GW-221 & $\mathrm{CR}$ & . & $\bullet$ & . & $\bullet$ & . & . \\
\hline GW-222 & $\mathrm{EF}$ & . & . & . & . & $\bullet$ & 5 Year (2014) \\
\hline GW-223 & $\mathrm{EF}$ & . & $\bullet$ & . & . & . & . \\
\hline GW-225 & $\mathrm{BC}$ & . & . & . & . & $\bullet$ & Annual \\
\hline GW-226 & $\mathrm{BC}$ & . & . & . & $\bullet$ & . & . \\
\hline GW-227 & $\mathrm{BC}$ & . & . & . & $\bullet$ & . & . \\
\hline GW-229 & $\mathrm{BC}$ & . & . & . & $\bullet$ & $\bullet$ & Annual \\
\hline GW-230 & $\mathrm{EF}$ & . & $\bullet$ & . & . & . & . \\
\hline GW-231 & CR & - & $\bullet$ & . & $\bullet$ & . & . \\
\hline GW-236 & $\mathrm{BC}$ & . & . & . & $\bullet$ & $\bullet$ & Biennial (Odd) \\
\hline GW-240 & $\mathrm{EF}$ & . & . & . & . & $\bullet$ & Annual \\
\hline GW-241 & CR & . & . & . & $\bullet$ & . & . \\
\hline GW-242 & $\mathrm{BC}$ & . & . & . & $\bullet$ & $\bullet$ & Biennial (Odd) \\
\hline GW-243 & $\mathrm{BC}$ & $\bullet$ & . & . & . & . & . \\
\hline GW-244 & $\mathrm{BC}$ & $\bullet$ & . & . & . & . & . \\
\hline GW-245 & $\mathrm{BC}$ & $\bullet$ & . & 7 & $\bullet$ & . & . \\
\hline GW-246 & $\mathrm{BC}$ & $\bullet$ & . & $\cdot$ & . & $\bullet$ & Annual \\
\hline
\end{tabular}


Table B.1 (continued)

\begin{tabular}{|c|c|c|c|c|c|c|c|}
\hline \multirow{3}{*}{\multicolumn{2}{|c|}{$\begin{array}{l}\text { Well Number and } \\
\text { Location }^{1}\end{array}$}} & \multicolumn{5}{|c|}{ Active Status Criteria $^{2}$} & \multirow{4}{*}{$\begin{array}{c}\begin{array}{c}\text { GWPP } \\
\text { Sampling } \\
\text { Frequency }\end{array} \\
.\end{array}$} \\
\hline & & \multicolumn{3}{|c|}{ Regulatory Monitoring } & \multirow{3}{*}{$\begin{array}{c}\begin{array}{r}\text { Hydrologic } \\
\text { Monitoring }\end{array} \\
.\end{array}$} & \multirow{3}{*}{$\begin{array}{c}\text { DOE Order } \\
\text { Monitoring } \\
.\end{array}$} & \\
\hline & & \multirow{2}{*}{$\begin{array}{c}\text { RCRA } \\
\bullet\end{array}$} & \multirow{2}{*}{$\begin{array}{c}\text { CERCLA } \\
\end{array}$} & \multirow{2}{*}{ SWDF } & & & \\
\hline GW-247 & $\mathrm{BC}$ & & & & & & \\
\hline GW-249 & $\mathrm{BC}$ & . & . & . & $\bullet$ & . & . \\
\hline GW-251 & $\mathrm{EF}$ & . & . & . & $\bullet$ & $\bullet$ & Annual \\
\hline GW-253 & $\mathrm{EF}$ & $\bullet$ & $\bullet$ & . & $\bullet$ & . & . \\
\hline GW-255 & $\mathrm{EF}$ & . & . & . & $\bullet$ & . & . \\
\hline GW-257 & $\mathrm{BC}$ & $\bullet$ & . & . & $\bullet$ & . & . \\
\hline GW-259 & $\mathrm{BC}$ & . & . & . & . & $\bullet$ & 5 Year (2013) \\
\hline GW-261 & $\mathrm{EF}$ & . & . & . & $\bullet$ & . & . \\
\hline GW-263 & $\mathrm{EF}$ & . & . & . & $\bullet$ & . & . \\
\hline GW-265 & $\mathrm{EF}$ &. & . & . & . & $\bullet$ & Annual \\
\hline GW-268 & $\mathrm{EF}$ & . & . & . & . & $\bullet$ & Annual \\
\hline GW-269 & $\mathrm{EF}$ & . & . & . & . & $\bullet$ & Annual \\
\hline GW-270 & $\mathrm{EF}$ & . & . & . & . & $\bullet$ & Annual \\
\hline GW-272 & EF & . & . & . & . & $\bullet$ & Biennial (Odd) \\
\hline GW-274 & $\mathrm{EF}$ & $\bullet$ & . & . & . & $\bullet$ & Annual \\
\hline GW-275 & $\mathrm{EF}$ & $\bullet$ & . & . & . & $\bullet$ & Annual \\
\hline GW-276 & $\mathrm{BC}$ & $\bullet$ & . & . & $\bullet$ & . & . \\
\hline GW-281 & $\mathrm{EF}$ & . & $\bullet$ & . & . & . & . \\
\hline GW-287 & $\mathrm{BC}$ & . & . & . & $\bullet$ & . & . \\
\hline GW-289 & $\mathrm{BC}$ & $\bullet$ & . & . & $\bullet$ & $\bullet$ & Annual \\
\hline GW-291 & $\mathrm{BC}$ & $\bullet$ & . & . & $\bullet$ & $\bullet$ & 5 Year $(2015)$ \\
\hline GW-292 & $\mathrm{CR}$ & - & . & . & $\bullet$ & . &. \\
\hline GW-293 & $\mathrm{CR}$ & - & . & . & . & . & . \\
\hline GW-294 & $\mathrm{CR}$ & - & . & . & . & . & . \\
\hline GW-296 & $\mathrm{CR}$ & - & . & . & . & . & . \\
\hline GW-298 & $\mathrm{CR}$ & $\bullet$ & . & . & $\bullet$ & . & . \\
\hline GW-299 & $\mathrm{CR}$ & . & . & . & $\bullet$ & . & . \\
\hline GW-300 & $\mathrm{CR}$ & . & . & . & $\bullet$ & . & . \\
\hline GW-301 & $\mathrm{CR}$ & - & . & . & $\bullet$ & . & . \\
\hline GW-302 & $\mathrm{CR}$ & . & . & . & $\bullet$ & . & . \\
\hline GW-303 & $\mathrm{CR}$ & . & . & . & $\bullet$ & . & . \\
\hline GW-304 & $\mathrm{CR}$ & . & . & . & $\bullet$ & . & . \\
\hline GW-305 & $\mathrm{CR}$ & . & $\bullet$ & $\bullet$ & $\bullet$ & . & . \\
\hline GW-306 & $\mathrm{BC}$ & . & . & . & . & $\bullet$ & 5 Year (2013) \\
\hline GW-307 & $\mathrm{BC}$ & . & . & . & $\bullet$ & $\bullet$ & Annual \\
\hline GW-309 & $\mathrm{BC}$ & . & . & . & $\bullet$ & $\bullet$ & 5 Year (2013) \\
\hline GW-310 & $\mathrm{BC}$ & . & . & . & $\bullet$ & $\bullet$ & Biennial (Even) \\
\hline GW-312 & $\mathrm{BC}$ & . & . & . & . & $\bullet$ & Biennial (Even) \\
\hline GW-315 & $\mathrm{BC}$ & . & . & . & . & $\bullet$ & Annual \\
\hline GW-316 & $\mathrm{BC}$ & . & . & . & $\bullet$ & . & . \\
\hline GW-322 & $\mathrm{CR}$ & . & . & . & $\bullet$ & $\bullet$ & Annual \\
\hline GW-323 & $\mathrm{BC}$ & . & . & . & $\bullet$ & . & . \\
\hline GW-325 & $\mathrm{BC}$ & . & . & . & $\bullet$ & . & . \\
\hline
\end{tabular}


Table B.1 (continued)

\begin{tabular}{|c|c|c|c|c|c|c|c|}
\hline \multirow{3}{*}{\multicolumn{2}{|c|}{$\begin{array}{l}\text { Well Number and } \\
\text { Location }^{1}\end{array}$}} & \multicolumn{5}{|c|}{ Active Status Criteria $^{2}$} & \multirow{4}{*}{$\begin{array}{c}\text { GWPP } \\
\text { Sampling } \\
\text { Frequency } \\
\end{array}$} \\
\hline & & \multicolumn{3}{|c|}{ Regulatory Monitoring } & \multirow{2}{*}{$\begin{array}{l}\text { Hydrologic } \\
\text { Monitoring }\end{array}$} & \multirow{3}{*}{$\begin{array}{c}\begin{array}{c}\text { DOE Order } \\
\text { Monitoring }\end{array} \\
\bullet\end{array}$} & \\
\hline & & \multirow{2}{*}{ RCRA } & \multirow{2}{*}{$\begin{array}{c}\text { CERCLA } \\
.\end{array}$} & \multirow{2}{*}{ SWDF } & & & \\
\hline GW-332 & $\mathrm{EF}$ & & & & . & & \\
\hline GW-334 & $\mathrm{EF}$ & . & . & . & $\bullet$ & . & . \\
\hline GW-335 & $\mathrm{EF}$ & . & . & . & $\bullet$ & . & . \\
\hline GW-337 & EF & . & . & . & . & $\bullet$ & Annual \\
\hline GW-339 & $\mathrm{CR}$ & . & . & . & $\bullet$ & . & . \\
\hline GW-345 & $\mathrm{BC}$ & . & . & . & $\bullet$ & . & . \\
\hline GW-347 & $\mathrm{BC}$ & . & . & . & $\bullet$ & . & . \\
\hline GW-349 & $\mathrm{EF}$ & . & . & . & $\bullet$ & . & . \\
\hline GW-363 & $\mathrm{BC}$ & $\bullet$ & - & . & . & . & . \\
\hline GW-364 & $\mathrm{BC}$ & . & . & . & $\bullet$ & . & . \\
\hline GW-365 & $\mathrm{BC}$ & . & . & . & . & $\bullet$ & Annual \\
\hline GW-367 & $\mathrm{BC}$ & . & . & . & . & $\bullet$ & 5 Year (2013) \\
\hline GW-370 & $\mathrm{BC}$ & . & . & . & $\bullet$ & . & . \\
\hline GW-372 & $\mathrm{BC}$ & . & . & . & $\bullet$ & . & . \\
\hline GW-380 & $\mathrm{EF}$ & . & $\bullet$ & . & $\bullet$ & . & . \\
\hline GW-381 & $\mathrm{EF}$ & . & $\bullet$ & . & . & $\bullet$ & Annual \\
\hline GW-382 & $\mathrm{EF}$ & . & $\bullet$ & . & . & . & 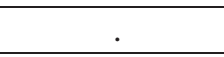 \\
\hline GW-383 & $\mathrm{EF}$ & . & $\bullet$ & . & $\bullet$ & $\bullet$ & Annual \\
\hline GW-384 & $\mathrm{EF}$ & . & $\bullet$ & . & . & . & . \\
\hline GW-505 & $\mathrm{EF}$ & . & . & . & . & $\bullet$ & Biennial (Odd) \\
\hline GW-508 & $\mathrm{EF}$ & . & . & . &. & $\bullet$ & Biennial (Odd) \\
\hline GW-511 & CR & . & . & . & $\bullet$ & . & - \\
\hline GW-512 & $\mathrm{CR}$ & . & . & . & $\bullet$ & . & . \\
\hline GW-514 & CR & $\bullet$ & . & . & . & $\bullet$ & 5 Year (2017) \\
\hline GW-521 & $\mathrm{CR}$ & $\bullet$ & . & $\bullet$ & $\bullet$ & . & . \\
\hline GW-522 & CR & . & . & $\bullet$ & $\bullet$ & . & . \\
\hline GW-526 & $\mathrm{BC}$ & . & . & . & . & $\bullet$ & Annual \\
\hline GW-531 & $\mathrm{BC}$ & . & . & . & $\bullet$ & $\bullet$ & Biennial (Odd) \\
\hline GW-537 & $\mathrm{BC}$ & . & . & . & $\bullet$ & $\bullet$ & Annual \\
\hline GW-539 & CR & . & . & . & $\bullet$ & . & . \\
\hline GW-540 & $\mathrm{CR}$ & . & . & - & . & . & . \\
\hline GW-541 & CR & . & . & . & $\bullet$ & . & . \\
\hline GW-542 & $\mathrm{CR}$ & . & . & . & $\bullet$ & . & . \\
\hline GW-543 & CR & . & . & . & $\bullet$ & . & . \\
\hline GW-544 & CR & . & . & . & $\bullet$ & . & 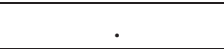 \\
\hline GW-546 & $\mathrm{CR}$ & . & . & . & $\bullet$ & . & . \\
\hline GW-557 & CR & $\bullet$ & . & - & $\bullet$ & . & . \\
\hline GW-558 & $\mathrm{CR}$ & . & . & . & $\bullet$ & . & . \\
\hline GW-559 & $\mathrm{CR}$ & . & . & . & $\bullet$ & . & . \\
\hline GW-560 & CR & . & . & - & $\bullet$ & . & . \\
\hline GW-562 & CR & $\bullet$ & . & - & $\bullet$ & . & . \\
\hline GW-564 & CR & . & . & - & $\bullet$ & . & . \\
\hline GW-601 & $\mathrm{BC}$ & . & . & . & . & $\bullet$ & Annual \\
\hline
\end{tabular}


Table B.1 (continued)

\begin{tabular}{|c|c|c|c|c|c|c|c|}
\hline \multirow{3}{*}{\multicolumn{2}{|c|}{$\begin{array}{l}\text { Well Number and } \\
\text { Location }^{1}\end{array}$}} & \multicolumn{5}{|c|}{ Active Status Criteria $^{2}$} & \multirow{3}{*}{$\begin{array}{c}\text { GWPP } \\
\text { Sampling } \\
\text { Frequency }\end{array}$} \\
\hline & & \multicolumn{3}{|c|}{ Regulatory Monitoring } & \multirow{3}{*}{$\begin{array}{c}\begin{array}{c}\text { Hydrologic } \\
\text { Monitoring }\end{array} \\
\bullet\end{array}$} & \multirow{3}{*}{$\begin{array}{c}\begin{array}{r}\text { DOE Order } \\
\text { Monitoring }\end{array} \\
. \\
\end{array}$} & \\
\hline & & \multirow{2}{*}{ RCRA } & \multirow{2}{*}{$\begin{array}{c}\text { CERCLA } \\
.\end{array}$} & \multirow{2}{*}{ SWDF } & & & \\
\hline GW-603 & $\mathrm{EF}$ & & & & & & . \\
\hline GW-605 & $\mathrm{EF}$ & $\bullet$ & $\bullet$ & . & $\bullet$ & . & . \\
\hline GW-606 & $\mathrm{EF}$ & $\bullet$ & $\bullet$ & . & $\bullet$ & . & . \\
\hline GW-608 & $\mathrm{CR}$ & $\bullet$ & . & . & $\bullet$ & $\bullet$ & Biennial (Even) \\
\hline GW-609 & $\mathrm{CR}$ & $\bullet$ & . & . & $\bullet$ & $\bullet$ & Biennial (Even) \\
\hline GW-610 & $\mathrm{CR}$ & . & . & . & $\bullet$ & . & . \\
\hline GW-611 & CR & . & . & . & $\bullet$ & $\bullet$ & Annual \\
\hline GW-612 & CR & . & . & . & $\bullet$ & $\bullet$ & 5 Year (2013) \\
\hline GW-613 & $\mathrm{BC}$ & . & . & . & $\bullet$ & . & \\
\hline GW-615 & $\mathrm{BC}$ & $\bullet$ & . & . & . & $\bullet$ & Annual \\
\hline GW-616 & $\mathrm{BC}$ & . & . & . & . & $\bullet$ & Annual \\
\hline GW-617 & $\mathrm{EF}$ & . & . & . & $\bullet$ & $\bullet$ & 5 Year $(2013)$ \\
\hline GW-618 & $\mathrm{EF}$ & . & $\bullet$ & . &. &. &. \\
\hline GW-619 & $\mathrm{EF}$ & . & . & . & $\bullet$ & $\bullet$ & Biennial (Even) \\
\hline GW-620 & EF & . & . & . & . & $\bullet$ & Biennial (Even) \\
\hline GW-621 & $\mathrm{BC}$ & . & . & . & $\bullet$ & . & . \\
\hline GW-622 & $\mathrm{BC}$ & . & . & . & $\bullet$ & . & \\
\hline GW-623 & $\mathrm{BC}$ & . & . & . & . & $\bullet$ & Annual \\
\hline GW-624 & $\mathrm{BC}$ & . & . & . & $\bullet$ & . & . \\
\hline GW-626 & $\mathrm{BC}$ & . & . & . & $\bullet$ & $\bullet$ & Biennial (Even) \\
\hline GW-627 & $\mathrm{BC}$ &. & . & . &. & $\bullet$ & Semiannual \\
\hline GW-629 & $\mathrm{BC}$ & . & . & . & . & $\bullet$ & TBD \\
\hline GW-630 & $\mathrm{BC}$ & . & . & . & $\bullet$ & . & . \\
\hline GW-633 & $\mathrm{EF}$ & . & . & . & . & $\bullet$ & Annual \\
\hline GW-638 & $\mathrm{BC}$ & . & . & . & $\bullet$ & . & . \\
\hline GW-639 & $\mathrm{BC}$ & . & - & . & . & . & . \\
\hline GW-641 & $\mathrm{BC}$ & . & . & . & $\bullet$ & . & . \\
\hline GW-642 & $\mathrm{BC}$ & . & . & . & $\bullet$ & . & . \\
\hline GW-645 & $\mathrm{BC}$ &. & . & . & $\bullet$ &. & . \\
\hline GW-652 & $\mathrm{BC}$ & . & . & . & $\bullet$ & . & \\
\hline GW-653 & $\mathrm{BC}$ & . & . & . & $\bullet$ & $\bullet$ & Annual \\
\hline GW-654 & $\mathrm{BC}$ & . & . & . & $\bullet$ & . &. \\
\hline GW-656 & $\mathrm{EF}$ & . & . & . & . & $\bullet$ & Annual \\
\hline GW-658 & $\mathrm{EF}$ &. & $\bullet$ & . &. & . & . \\
\hline GW-674 & CR & . & . & . & $\bullet$ & . & 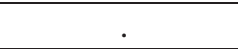 \\
\hline GW-676 & CR & . & . & . & $\bullet$ & . & . \\
\hline GW-677 & CR & . & . & . & $\bullet$ & . & . \\
\hline GW-678 & CR & . & . & . & $\bullet$ & . & . \\
\hline GW-679 & $\mathrm{CR}$ & . & . & . & $\bullet$ & . & . \\
\hline GW-680 & CR & . & . & . & $\bullet$ & . & . \\
\hline GW-683 & BC & . & $\bullet$ & . & $\bullet$ & . & . \\
\hline GW-684 & $\mathrm{BC}$ & . & $\bullet$ & . & . & . & . \\
\hline GW-686 & EF & . & -1 & . & $\bullet$ & $\bullet$ & Annual \\
\hline
\end{tabular}


Table B.1 (continued)

\begin{tabular}{|c|c|c|c|c|c|c|c|}
\hline \multirow{3}{*}{\multicolumn{2}{|c|}{$\begin{array}{l}\text { Well Number and } \\
\text { Location }^{1}\end{array}$}} & \multicolumn{5}{|c|}{ Active Status Criteria $^{2}$} & \multirow{4}{*}{$\begin{array}{c}\begin{array}{c}\text { GWPP } \\
\text { Sampling } \\
\text { Frequency }\end{array} \\
\text { Annual } \\
\end{array}$} \\
\hline & & \multicolumn{3}{|c|}{ Regulatory Monitoring } & \multirow{2}{*}{$\begin{array}{l}\text { Hydrologic } \\
\text { Monitoring }\end{array}$} & \multirow{3}{*}{$\begin{array}{c}\begin{array}{c}\text { DOE Order } \\
\text { Monitoring }\end{array} \\
\bullet\end{array}$} & \\
\hline & & \multirow{2}{*}{ RCRA } & \multirow{2}{*}{$\begin{array}{c}\text { CERCLA } \\
\end{array}$} & \multirow{2}{*}{ SWDF } & & & \\
\hline GW-690 & $\mathrm{EF}$ & & & & . & & \\
\hline GW-691 & $\mathrm{EF}$ & . & . & . & $\bullet$ & $\bullet$ & Semiannual \\
\hline GW-692 & $\mathrm{EF}$ & . & . & . & . & $\bullet$ & Annual \\
\hline GW-695 & $\mathrm{BC}$ & . & . & . & $\bullet$ & . & . \\
\hline GW-696 & $\mathrm{EF}$ & . & . & . & $\bullet$ & . & . \\
\hline GW-698 & $\mathrm{EF}$ & . & . & . & . & $\bullet$ & Semiannual \\
\hline GW-700 & $\mathrm{EF}$ & . & . & . & . & $\bullet$ & Annual \\
\hline GW-703 & $\mathrm{BC}$ & . & . & . & . & $\bullet$ & Annual \\
\hline GW-704 & $\mathrm{BC}$ & . & $\bullet$ & . & . & . &. \\
\hline GW-706 & $\mathrm{BC}$ & . & $\bullet$ & . & . & . & . \\
\hline GW-709 & CR & . & . & - & $\bullet$ & . & . \\
\hline GW-712 & $\mathrm{BC}$ & $\bullet$ & $\bullet$ & . & . & . & . \\
\hline GW-713 & $\mathrm{BC}$ & $\bullet$ & $\bullet$ & . & . & . & . \\
\hline GW-714 & $\mathrm{BC}$ & $\bullet$ & $\bullet$ & . & . & . & . \\
\hline GW-715 & $\mathrm{BC}$ & . & . & . & $\bullet$ & . & . \\
\hline GW-722 (5) & $\mathrm{EF}$ & . & $\bullet$ & . & . & $\bullet$ & Annual \\
\hline GW-724 & $\mathrm{BC}$ & . & . & . & . & $\bullet$ & Annual \\
\hline GW-725 & $\mathrm{BC}$ & . & . & . & . & $\bullet$ & Annual \\
\hline GW-726 (8) & $\mathrm{BC}$ & . & . & . & . & $\bullet$ & 5 Year (2014) \\
\hline GW-727 (10) & $\mathrm{BC}$ & . & . & . & . & $\bullet$ & TBD \\
\hline GW-729 (10) & $\mathrm{BC}$ & . & . & . & . & $\bullet$ & TBD \\
\hline GW-730 (8) & $\mathrm{BC}$ & . & . & . & . & $\bullet$ & TBD \\
\hline GW-731 & $\mathrm{CR}$ & - & . & . & $\bullet$ & . & . \\
\hline GW-732 & CR & - & . & . & $\bullet$ & . & . \\
\hline GW-733 & EF & $\bullet$ & $\bullet$ & . & $\bullet$ & . & . \\
\hline GW-734 & $\mathrm{EF}$ &. & $\bullet$ & . & $\bullet$ &. &. \\
\hline GW-735 & $\mathrm{EF}$ & . & $\bullet$ & . & $\bullet$ & $\bullet$ & Biennial (Odd) \\
\hline GW-738 & $\mathrm{BC}$ & . & . & . & . & $\bullet$ & Annual \\
\hline GW-740 & $\mathrm{BC}$ & . & . & . & . & $\bullet$ & Annual \\
\hline GW-743 & $\mathrm{CR}$ & . & . & . & $\bullet$ & . & . \\
\hline GW-744 & $\mathrm{EF}$ & . & $\bullet$ & . & . & $\bullet$ & Annual \\
\hline GW-746 & $\mathrm{EF}$ & . & . & . & $\bullet$ & . & . \\
\hline GW-747 & $\mathrm{EF}$ & . & $\bullet$ & . & . & $\bullet$ & Annual \\
\hline GW-748 & $\mathrm{EF}$ & . & . & . & $\bullet$ & $\bullet$ & Biennial (Even) \\
\hline GW-750 & EF & . & $\bullet$ & . & . & $\bullet$ & Biennial (Odd) \\
\hline GW-752 & $\mathrm{EF}$ & . & . & . & $\bullet$ & . & . \\
\hline GW-754 & $\mathrm{EF}$ & . & . & . & $\bullet$ & . & . \\
\hline GW-756 & $\mathrm{EF}$ & . & . & . & $\bullet$ & . & . \\
\hline GW-757 & $\mathrm{CR}$ & . & . & - & $\bullet$ & . & . \\
\hline GW-759 & $\mathrm{EF}$ & . & . & . & $\bullet$ & . & . \\
\hline GW-761 & $\mathrm{EF}$ & . & . & . & $\bullet$ & . & . \\
\hline GW-762 & $\mathrm{EF}$ & . & $\bullet$ & . & . & . & . \\
\hline GW-763 & $\mathrm{EF}$ & . & $\bullet$ & . & $\bullet$ & $\bullet$ & Annual \\
\hline
\end{tabular}


Table B.1 (continued)

\begin{tabular}{|c|c|c|c|c|c|c|c|}
\hline \multirow{3}{*}{\multicolumn{2}{|c|}{$\begin{array}{l}\text { Well Number and } \\
\text { Location }^{1}\end{array}$}} & \multicolumn{5}{|c|}{ Active Status Criteria $^{2}$} & \multirow{4}{*}{$\begin{array}{c}\text { GWPP } \\
\text { Sampling } \\
\text { Frequency } \\
\text { Biennial (Odd) }\end{array}$} \\
\hline & & \multicolumn{3}{|c|}{ Regulatory Monitoring } & \multirow{3}{*}{$\begin{array}{c}\begin{array}{c}\text { Hydrologic } \\
\text { Monitoring }\end{array} \\
\bullet\end{array}$} & \multirow{3}{*}{$\begin{array}{c}\text { DOE Order } \\
\text { Monitoring } \\
\bullet\end{array}$} & \\
\hline & & \multirow{2}{*}{ RCRA } & \multirow{2}{*}{$\frac{\text { CERCLA }}{.}$} & \multirow{2}{*}{ SWDF } & & & \\
\hline GW-765 & $\mathrm{EF}$ & & & & & & \\
\hline GW-767 & $\mathrm{EF}$ & . & . & . & $\bullet$ & . & . \\
\hline GW-769 & $\mathrm{EF}$ & . & . & . & . & $\bullet$ & Semiannual \\
\hline GW-770 & $\mathrm{EF}$ & . & . & . & $\bullet$ & $\bullet$ & Annual \\
\hline GW-774 & $\mathrm{EF}$ & . & . & . & $\bullet$ & . & . \\
\hline GW-775 & $\mathrm{EF}$ & . & . & . & . & $\bullet$ & Biennial (Odd) \\
\hline GW-776 & $\mathrm{EF}$ & . & . & . & $\bullet$ & $\bullet$ & Biennial (Odd) \\
\hline GW-777 & EF & . & . & . & . & $\bullet$ & TBD \\
\hline GW-778 & $\mathrm{EF}$ & . & . & . & $\bullet$ & . & . \\
\hline GW-779 & $\mathrm{EF}$ & . & . & . & . & $\bullet$ & Biennial (Odd) \\
\hline GW-781 & $\mathrm{EF}$ & . & . & . & . & $\bullet$ & Annual \\
\hline GW-782 & $\mathrm{EF}$ & . & . & . & . & $\bullet$ & Annual \\
\hline GW-783 & $\mathrm{EF}$ & . & . & . & $\bullet$ & $\bullet$ & Annual \\
\hline GW-790 & $\mathrm{BC}$ & . & . & . & . & $\bullet$ & TBD \\
\hline GW-791 & EF & . & . & . & . & $\bullet$ & Annual \\
\hline GW-792 & $\mathrm{EF}$ & . & . & . & $\bullet$ & $\bullet$ & Biennial (Even) \\
\hline GW-795 & $\mathrm{BC}$ & . & . & . & $\bullet$ & . & . \\
\hline GW-796 & $\mathrm{CR}$ & $\bullet$ & . & - & $\bullet$ & . & . \\
\hline GW-797 & CR & . & $\bullet$ & - & $\bullet$ & . & . \\
\hline GW-798 & $\mathrm{CR}$ & . & $\bullet$ & - & $\bullet$ & . & . \\
\hline GW-799 & CR & $\bullet$ & . & - & $\bullet$ & . & . \\
\hline GW-800 & $\mathrm{BC}$ & . & . & . & $\bullet$ & . & . \\
\hline GW-801 & $\mathrm{CR}$ & $\bullet$ & . & - & $\bullet$ & . & . \\
\hline GW-802 & $\mathrm{EF}$ & . & $\bullet$ & . & . & . & . \\
\hline GW-816 & EF & . & . & . & . & $\bullet$ & Annual \\
\hline GW-820 & $\mathrm{EF}$ & . & . & . &. & $\bullet$ & Annual \\
\hline GW-827 & CR & . & . & . & $\bullet$ & . & . \\
\hline GW-829 & $\mathrm{BC}$ & . & . & . & $\bullet$ & $\bullet$ & Biennial (Even) \\
\hline GW-831 & CR & $\bullet$ & . & . & $\bullet$ & . & . \\
\hline GW-832 & EF & . & $\bullet$ & . & $\bullet$ & . & . \\
\hline GW-835 & $\mathrm{BC}$ & . & . & . & $\bullet$ & . & . \\
\hline GW-841 & $\mathrm{CR}$ & . & $\bullet$ & . & . & . & . \\
\hline GW-842 & $\mathrm{CR}$ & . & $\bullet$ & . & . & . & . \\
\hline GW-845 & $\mathrm{EF}$ & . & $\bullet$ & . & . & . & . \\
\hline GW-916 & $\mathrm{BC}$ & . & - & . & $\bullet$ & . & . \\
\hline GW-917 & $\mathrm{BC}$ & . & - & . & $\bullet$ & . & . \\
\hline GW-918 & $\mathrm{BC}$ & . & - & . & $\bullet$ & . & . \\
\hline GW-920 & $\mathrm{BC}$ & . & - & . & . & . & . \\
\hline GW-921 & $\mathrm{BC}$ & . & $\square$ & . & $\bullet$ & . & . \\
\hline GW-922 & $\mathrm{BC}$ & . & - & . & $\bullet$ & . & . \\
\hline GW-923 & $\mathrm{BC}$ & . & . & . & $\bullet$ & . & . \\
\hline GW-924 & $\mathrm{BC}$ & . & - & . & $\bullet$ & . & . \\
\hline GW-925 & $\mathrm{BC}$ & . & - & . & . & . & . \\
\hline
\end{tabular}


Table B.1 (continued)

\begin{tabular}{|c|c|c|c|c|c|c|c|}
\hline \multirow{3}{*}{\multicolumn{2}{|c|}{$\begin{array}{l}\text { Well Number and } \\
\text { Location }^{1}\end{array}$}} & \multicolumn{5}{|c|}{ Active Status Criteria $^{2}$} & \multirow{4}{*}{$\begin{array}{c}\begin{array}{c}\text { GWPP } \\
\text { Sampling } \\
\text { Frequency }\end{array} \\
\end{array}$} \\
\hline & & \multicolumn{3}{|c|}{ Regulatory Monitoring } & \multirow{3}{*}{$\begin{array}{c}\begin{array}{c}\text { Hydrologic } \\
\text { Monitoring }\end{array} \\
. \\
\end{array}$} & \multirow{3}{*}{$\begin{array}{c}\begin{array}{r}\text { DOE Order } \\
\text { Monitoring }\end{array} \\
. \\
\end{array}$} & \\
\hline & & \multirow{2}{*}{ RCRA } & \multirow{2}{*}{$\frac{\text { CERCLA }}{n}$} & \multirow{2}{*}{ SWDF } & & & \\
\hline GW-926 & $\mathrm{BC}$ & & & & & & \\
\hline GW-927 & $\mathrm{BC}$ & . & a & . & . & . &. \\
\hline GW-928 & $\mathrm{EF}$ & . & . & . & . & $\bullet$ & Biennial (Even) \\
\hline GW-929 & $\mathrm{EF}$ & . & . & . & . & $\bullet$ & Biennial (Even) \\
\hline GW-930 & $\mathrm{EF}$ & . & . & . & . & $\bullet$ & Biennial (Even) \\
\hline GW-931 & $\mathrm{EF}$ & . & . & . & . & $\bullet$ & Biennial (Even) \\
\hline GW-934 (8) & $\mathrm{EF}$ & . & . & . & . & $\bullet$ & Annual \\
\hline GW-954 (3) & $\mathrm{EF}$ & . & . & . & . & $\bullet$ & TBD \\
\hline GW-956 (4) & $\mathrm{EF}$ & . & . & . & . & $\bullet$ & TBD \\
\hline GW-959 & $\mathrm{EF}$ & . & . & . & . & $\bullet$ & Biennial (Odd) \\
\hline GW-960 & $\mathrm{EF}$ & . & . & . & $\bullet$ & $\bullet$ & Biennial (Odd) \\
\hline GW-961 & $\mathrm{BC}$ & . & - & . & . & . & . \\
\hline GW-964 & $\mathrm{BC}$ & . & - & . & . & . & . \\
\hline GW-965 & $\mathrm{BC}$ & . & - & . & . & . & . \\
\hline GW-966 & $\mathrm{EF}$ & . & . & . & . & $\bullet$ & TBD \\
\hline
\end{tabular}

Notes:

1. ( ) - Number of discrete depth intervals monitored in the well (Westbay ${ }^{\mathrm{TM}}$ or Barcad $^{\mathrm{TM}}$ wells)

BC - Bear Creek Hydrogeologic Regime

CR - Chestnut Ridge Hydrogeologic Regime

EF - Upper East Fork Poplar Creek Hydrogeologic Regime

2. Regulatory Monitoring - Specified well designated for groundwater monitoring performed in accordance with one or more of the following regulatory monitoring programs (“.” - not applicable for specified well):

Resource Conservation and Recovery Act (RCRA)

- - Post-Closure Detection Monitoring

- - Post-Closure Corrective Action Monitoring

Comprehensive Environmental Response, Compensation, and Liability Act (CERCLA)

- - Detection Monitoring

- - Remediation Effectiveness Monitoring

Nonhazardous Solid Waste Disposal Facility (SWDF)

- Detection Monitoring

- - Assessment Monitoring Phase 3

Hydrologic Monitoring - Specified well designated for annual groundwater elevation monitoring.

DOE Order Monitoring - Specified well designated for site-wide groundwater monitoring per the objectives and requirements defined in DOE Order 436.1 and DOE Order 458.1. 


\section{Table B.1 (continued)}

\section{Notes: (continued)}

3. Groundwater Protection Program (GWPP) sampling frequency for DOE Order Monitoring.

$$
\begin{aligned}
& \text { Annual } \text { groundwater sample collected each year, alternating seasonally wet and dry } \\
& \text { weather/flow conditions } \\
& \text { Biennial }- \text { groundwater sample collected every two years (even or odd numbered year) } \\
& \text { Semiannual }- \text { groundwater sample collected during seasonally wet and dry weather/flow conditions } \\
& \text { TBD }- \text { to be determined }
\end{aligned}
$$

5 Year - groundwater sample collected every five years (year of next sampling event) 
Table B.2 Groundwater monitoring wells that are granted inactive status under the Y-12 Groundwater Protection Program

\begin{tabular}{|c|c|c|c|c|}
\hline \multirow{2}{*}{\multicolumn{2}{|c|}{$\begin{array}{l}\text { Well Number and } \\
\text { Location }^{1}\end{array}$}} & \multicolumn{3}{|c|}{ Inactive Status Criteria $^{2}$} \\
\hline & & \multirow{2}{*}{$\begin{array}{c}\text { Unknown/Inadequate } \\
\text { Well Construction }\end{array}$} & \multirow{2}{*}{$\begin{array}{c}\begin{array}{c}\text { Low Priority/Need for } \\
\text { Additional Data }\end{array} \\
\bullet\end{array}$} & \multirow{2}{*}{$\begin{array}{c}\begin{array}{c}\text { Well Redundancy } \\
\text { Evaluation }\end{array} \\
\end{array}$} \\
\hline $54-2 \mathrm{~A}$ & EF & & & \\
\hline 55-1B & EF & . & $\bullet$ & . \\
\hline $55-1 \mathrm{C}$ & EF & . & . & $\bullet$ \\
\hline 56-7A & EF & . & $\bullet$ & . \\
\hline $58-2 \mathrm{~A}$ & EF & . & $\bullet$ & . \\
\hline $59-1 \mathrm{~A}$ & EF & . & $\bullet$ & . \\
\hline $59-1 \mathrm{~B}$ & $\mathrm{EF}$ & . & . & $\bullet$ \\
\hline $59-1 \mathrm{C}$ & EF & . & . & $\bullet$ \\
\hline $60-1 \mathrm{~B}$ & EF & . & . & $\bullet$ \\
\hline CH-143 & $\mathrm{CR}$ & $\bullet$ & . & . \\
\hline $\mathrm{CH}-157$ & $\mathrm{CR}$ & $\bullet$ & . & . \\
\hline $\mathrm{CH}-185$ & $\mathrm{CR}$ & $\bullet$ & . & . \\
\hline CH-189 & $\mathrm{CR}$ & $\bullet$ & . & . \\
\hline GW-011 & $\mathrm{BC}$ & . & $\bullet$ & . \\
\hline GW-013 & $\mathrm{BC}$ & . & . & $\bullet$ \\
\hline GW-015 & $\mathrm{BC}$ & . & $\bullet$ & . \\
\hline GW-017 & $\mathrm{BC}$ & . & $\bullet$ & . \\
\hline GW-018 & $\mathrm{BC}$ & . & $\bullet$ & . \\
\hline GW-040 & $\mathrm{BC}$ & . & $\bullet$ & . \\
\hline GW-042 & $\mathrm{BC}$ & . & $\bullet$ & . \\
\hline GW-045 & $\mathrm{BC}$ & . & $\bullet$ & . \\
\hline GW-054 & $\mathrm{BC}$ & . & . & $\bullet$ \\
\hline GW-055 & $\mathrm{BC}$ & . & $\bullet$ & . \\
\hline GW-056 & $\mathrm{BC}$ & . & $\bullet$ & . \\
\hline GW-061 & $\mathrm{BC}$ & . & $\bullet$ & . \\
\hline GW-062 & $\mathrm{BC}$ & . & $\bullet$ & . \\
\hline GW-064 & $\mathrm{BC}$ & . & $\bullet$ & . \\
\hline GW-066 & $\mathrm{BC}$ & . & $\bullet$ & . \\
\hline GW-067 & $\mathrm{BC}$ & $\bullet$ & . & . \\
\hline GW-070 & $\mathrm{BC}$ & . & $\bullet$ & . \\
\hline GW-072 & $\mathrm{BC}$ & . & . & $\bullet$ \\
\hline GW-073 & $\mathrm{BC}$ & . & . & $\bullet$ \\
\hline GW-074 & $\mathrm{BC}$ & . & $\bullet$ & . \\
\hline GW-081 & $\mathrm{BC}$ & . & $\bullet$ & . \\
\hline GW-083 & $\mathrm{BC}$ & . & . & $\bullet$ \\
\hline GW-094 & $\mathrm{BC}$ & . & . & $\bullet$ \\
\hline GW-095 & $\mathrm{BC}$ & . & . & $\bullet$ \\
\hline GW-096 & $\mathrm{BC}$ & . & $\bullet$ & . \\
\hline GW-097A & $\mathrm{BC}$ & . & $\bullet$ & . \\
\hline GW-117 & $\mathrm{BC}$ & . & $\bullet$ & . \\
\hline GW-118 & $\mathrm{BC}$ & . & $\bullet$ & . \\
\hline GW-119 & $\mathrm{BC}$ & . & $\bullet$ & . \\
\hline
\end{tabular}


Table B.2 (continued)

\begin{tabular}{|c|c|c|c|c|}
\hline \multirow{2}{*}{\multicolumn{2}{|c|}{$\begin{array}{l}\text { Well Number and } \\
\text { Location }^{1}\end{array}$}} & \multicolumn{3}{|c|}{ Inactive Status Criteria $^{2}$} \\
\hline & & \multirow{2}{*}{$\begin{array}{c}\begin{array}{c}\text { Unknown/Inadequate } \\
\text { Well Construction }\end{array} \\
.\end{array}$} & \multirow{2}{*}{$\begin{array}{c}\text { Low Priority/Need for } \\
\text { Additional Data } \\
\end{array}$} & \multirow{2}{*}{$\begin{array}{c}\begin{array}{c}\text { Well Redundancy } \\
\text { Evaluation }\end{array} \\
\bullet \\
\end{array}$} \\
\hline GW-120 & $\mathrm{BC}$ & & & \\
\hline GW-121 & $\mathrm{BC}$ & . & $\bullet$ & . \\
\hline GW-123 & $\mathrm{BC}$ & . & $\bullet$ & . \\
\hline GW-124 & $\mathrm{BC}$ & . & $\bullet$ & . \\
\hline GW-125 & $\mathrm{BC}$ & . & $\bullet$ & . \\
\hline GW-126 & $\mathrm{BC}$ & . & $\bullet$ & . \\
\hline GW-131 & EF & . & $\bullet$ & . \\
\hline GW-132 & EF & . & $\bullet$ & . \\
\hline GW-133 & $\mathrm{BC}$ & . & $\bullet$ & . \\
\hline GW-135 & $\mathrm{BC}$ & . & $\bullet$ & . \\
\hline GW-146 & $\mathrm{CR}$ & . & $\bullet$ & . \\
\hline GW-147 & $\mathrm{CR}$ & . & $\bullet$ & . \\
\hline GW-150 & $\mathrm{EF}$ & . & . & $\bullet$ \\
\hline GW-158 & $\mathrm{CR}$ & . & $\bullet$ & . \\
\hline GW-162 & $\mathrm{BC}$ & . & $\bullet$ & . \\
\hline GW-163 & $\mathrm{BC}$ & . & $\bullet$ & . \\
\hline GW-164 & $\mathrm{BC}$ & . & $\bullet$ & . \\
\hline GW-165 & $\mathrm{CR}$ & . & $\bullet$ & . \\
\hline GW-166 & $\mathrm{CR}$ & . & $\bullet$ & . \\
\hline GW-181 & $\mathrm{CR}$ & . & . & $\bullet$ \\
\hline GW-183 & EF & . & . & $\bullet$ \\
\hline GW-185 & $\mathrm{CR}$ & . & $\bullet$ & . \\
\hline GW-187 & $\mathrm{CR}$ & . & $\bullet$ & . \\
\hline GW-189 & $\mathrm{CR}$ & . & $\bullet$ & . \\
\hline GW-191 & $\mathrm{EF}$ & . & . & $\bullet$ \\
\hline GW-194 & EF & . &. & $\bullet$ \\
\hline GW-196 & EF & . & $\bullet$ & . \\
\hline GW-197 & $\mathrm{EF}$ & . & $\bullet$ & . \\
\hline GW-198 & $\mathrm{EF}$ & . & $\bullet$ & . \\
\hline GW-206 & EF & . & $\bullet$ & . \\
\hline GW-207 & $\mathrm{EF}$ & . & $\bullet$ & . \\
\hline GW-208 & EF & . & $\bullet$ & . \\
\hline GW-218 & EF & . & . & $\bullet$ \\
\hline GW-224 & $\mathrm{CR}$ & . & $\bullet$ & . \\
\hline GW-228 & $\mathrm{BC}$ & . & $\bullet$ & . \\
\hline GW-232 & $\mathrm{EF}$ & . & $\bullet$ &. \\
\hline GW-237 & $\mathrm{BC}$ & . & . & $\bullet$ \\
\hline GW-239 & EF & . & . & $\bullet$ \\
\hline GW-248 & $\mathrm{BC}$ & . & . & $\bullet$ \\
\hline GW-250 & $\mathrm{BC}$ & . & . & $\bullet$ \\
\hline GW-252 & EF & . &. & $\bullet$ \\
\hline GW-258 & $\mathrm{BC}$ & . & $\bullet$ & . \\
\hline GW-262 & $\mathrm{EF}$ & 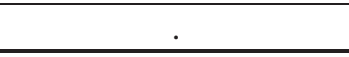 & $\bullet$ & . \\
\hline
\end{tabular}


Table B.2 (continued)

\begin{tabular}{|c|c|c|c|c|}
\hline \multirow{2}{*}{\multicolumn{2}{|c|}{$\begin{array}{l}\text { Well Number and } \\
\text { Location }^{1}\end{array}$}} & \multicolumn{3}{|c|}{ Inactive Status Criteria $^{2}$} \\
\hline & & \multirow{2}{*}{$\begin{array}{c}\begin{array}{c}\text { Unknown/Inadequate } \\
\text { Well Construction }\end{array} \\
.\end{array}$} & \multirow{2}{*}{$\begin{array}{c}\begin{array}{c}\text { Low Priority/Need for } \\
\text { Additional Data }\end{array} \\
\bullet\end{array}$} & $\begin{array}{c}\text { Well Redundancy } \\
\text { Evaluation }\end{array}$ \\
\hline GW-264 & $\mathrm{EF}$ & & & . \\
\hline GW-268 & EF & . & . & $\bullet$ \\
\hline GW-271 & EF & . & - & . \\
\hline GW-273 & EF & . & . & - \\
\hline GW-277 & $\mathrm{BC}$ & . & . & - \\
\hline GW-282 & EF & . & . & - \\
\hline GW-283 & EF & . & . & - \\
\hline GW-284 & EF & . & - & . \\
\hline GW-285 & $\mathrm{EF}$ & . & - & . \\
\hline GW-286 & $\mathrm{BC}$ & . & - & . \\
\hline GW-288 & $\mathrm{BC}$ & . & $\bullet$ & . \\
\hline GW-290 & $\mathrm{BC}$ & . & - & . \\
\hline GW-308 & $\mathrm{BC}$ & . & - & . \\
\hline GW-311 & $\mathrm{BC}$ & . & - & . \\
\hline GW-313 & $\mathrm{BC}$ & . & . & - \\
\hline GW-314 & $\mathrm{BC}$ & . & . & - \\
\hline GW-317 & $\mathrm{BC}$ & . & - & . \\
\hline GW-318 & CR & . & $\bullet$ & . \\
\hline GW-319 & CR & . & - & . \\
\hline GW-324 & $\mathrm{BC}$ & . & - & . \\
\hline GW-331 & $\mathrm{EF}$ & . & $\bullet$ & . \\
\hline GW-333 & EF & . & - & . \\
\hline GW-336 & EF & . & . & - \\
\hline GW-338 & $\mathrm{EF}$ & . & . & $\bullet$ \\
\hline GW-342 & $\mathrm{BC}$ & . & - & . \\
\hline GW-343 & $\mathrm{BC}$ & . & - & . \\
\hline GW-344 & $\mathrm{BC}$ & . & - & . \\
\hline GW-346 & $\mathrm{BC}$ & . & $\bullet$ & . \\
\hline GW-348 & $\mathrm{BC}$ & . & . & $\bullet$ \\
\hline GW-350 & EF & . & - & . \\
\hline GW-366 & $\mathrm{BC}$ & . &. & $\bullet$ \\
\hline GW-368 & $\mathrm{BC}$ & . & . & $\bullet$ \\
\hline GW-369 & $\mathrm{BC}$ & . & . & - \\
\hline GW-371 & $\mathrm{BC}$ & . & $\bullet$ & . \\
\hline GW-373 & $\mathrm{BC}$ & . & - & . \\
\hline GW-374 & $\mathrm{BC}$ & . & - & . \\
\hline GW-375 & $\mathrm{BC}$ & . & . & $\bullet$ \\
\hline GW-376 & $\mathrm{BC}$ & . & - & . \\
\hline GW-385 & EF & . & . & - \\
\hline GW-513 & CR & . & . & $\bullet$ \\
\hline GW-520 & $\mathrm{BC}$ & . & . & $\bullet$ \\
\hline GW-532 & $\mathrm{BC}$ & . & $\bullet$ & . \\
\hline GW-533 & $\mathrm{BC}$ & - & - & . \\
\hline
\end{tabular}


Table B.2 (continued)

\begin{tabular}{|c|c|c|c|c|}
\hline \multirow{2}{*}{\multicolumn{2}{|c|}{$\begin{array}{l}\text { Well Number and } \\
\text { Location }^{1}\end{array}$}} & \multicolumn{3}{|c|}{ Inactive Status Criteria $^{2}$} \\
\hline & & \multirow{2}{*}{$\begin{array}{c}\begin{array}{c}\text { Unknown/Inadequate } \\
\text { Well Construction }\end{array} \\
.\end{array}$} & \multirow{2}{*}{$\begin{array}{c}\text { Low Priority/Need for } \\
\text { Additional Data } \\
\bullet\end{array}$} & \multirow{2}{*}{$\begin{array}{c}\begin{array}{c}\text { Well Redundancy } \\
\text { Evaluation }\end{array} \\
.\end{array}$} \\
\hline GW-534 & $\mathrm{BC}$ & & & \\
\hline GW-535 & $\mathrm{BC}$ & . & $\bullet$ & . \\
\hline GW-538 & $\mathrm{BC}$ & . & $\bullet$ & . \\
\hline GW-563 & $\mathrm{CR}$ & . & $\bullet$ & . \\
\hline GW-567 & $\mathrm{CR}$ & . & $\bullet$ & . \\
\hline GW-569 & $\mathrm{CR}$ & . & $\bullet$ & . \\
\hline GW-576 & $\mathrm{CR}$ & . & $\bullet$ & . \\
\hline GW-602 & $\mathrm{BC}$ & . & $\bullet$ & . \\
\hline GW-604 & EF & . & $\bullet$ & . \\
\hline GW-614 & $\mathrm{BC}$ & . & $\bullet$ & . \\
\hline GW-625 & $\mathrm{BC}$ & . & $\bullet$ & . \\
\hline GW-628 & $\mathrm{BC}$ & . & $\bullet$ & . \\
\hline GW-631 & EF & . & $\bullet$ & . \\
\hline GW-632 & EF & . & $\bullet$ & . \\
\hline GW-634 & $\mathrm{EF}$ & . & $\bullet$ & . \\
\hline GW-636 & $\mathrm{BC}$ & . & . & $\bullet$ \\
\hline GW-637 & $\mathrm{BC}$ & . & . & $\bullet$ \\
\hline GW-640 & $\mathrm{BC}$ & . & $\bullet$ & . \\
\hline GW-643 & $\mathrm{BC}$ & . & $\bullet$ & . \\
\hline GW-647 & $\mathrm{BC}$ & . & $\bullet$ & . \\
\hline GW-649 & $\mathrm{BC}$ & . & $\bullet$ & . \\
\hline GW-651 & $\mathrm{BC}$ & . &. & $\bullet$ \\
\hline GW-655 & $\mathrm{BC}$ & . & $\bullet$ & . \\
\hline GW-657 & EF & . & . & $\bullet$ \\
\hline GW-659 & $\mathrm{EF}$ & . & . & $\bullet$ \\
\hline GW-673 & $\mathrm{CR}$ & . & $\bullet$ & . \\
\hline GW-681 & $\mathrm{CR}$ & . & $\bullet$ & . \\
\hline GW-682 & $\mathrm{CR}$ & . & $\bullet$ & . \\
\hline GW-685 & $\mathrm{BC}$ & . & $\bullet$ & . \\
\hline GW-688 & $\mathrm{EF}$ & . & $\bullet$ & . \\
\hline GW-693 & EF & . & $\bullet$ & . \\
\hline GW-694 & $\mathrm{BC}$ & . & . & $\bullet$ \\
\hline GW-697 & EF & . & $\bullet$ & . \\
\hline GW-699 & EF & . & $\bullet$ & . \\
\hline GW-701 & $\mathrm{EF}$ & . & $\bullet$ & . \\
\hline GW-702 & EF & . & $\bullet$ & . \\
\hline GW-705 & $\mathrm{BC}$ & . & $\bullet$ & . \\
\hline GW-710 & $\mathrm{BC}$ & . & $\bullet$ & . \\
\hline GW-711 & $\mathrm{BC}$ & . & $\bullet$ & . \\
\hline GW-723 & $\mathrm{BC}$ & . & $\bullet$ & . \\
\hline GW-728 & $\mathrm{BC}$ & $\bullet$ & . & . \\
\hline GW-736 & $\mathrm{BC}$ & . & . & $\bullet$ \\
\hline GW-737 & $\mathrm{BC}$ & . & $\bullet$ & . \\
\hline
\end{tabular}


Table B.2 (continued)

\begin{tabular}{|c|c|c|c|c|}
\hline \multirow{2}{*}{\multicolumn{2}{|c|}{$\begin{array}{l}\text { Well Number and } \\
\text { Location }^{1}\end{array}$}} & \multicolumn{3}{|c|}{ Inactive Status Criteria $^{2}$} \\
\hline & & \multirow{2}{*}{$\begin{array}{c}\begin{array}{c}\text { Unknown/Inadequate } \\
\text { Well Construction }\end{array} \\
.\end{array}$} & \multirow{2}{*}{$\begin{array}{c}\text { Low Priority/Need for } \\
\text { Additional Data }\end{array}$} & \multirow{2}{*}{$\begin{array}{c}\begin{array}{c}\text { Well Redundancy } \\
\text { Evaluation }\end{array} \\
\bullet\end{array}$} \\
\hline GW-739 & $\mathrm{BC}$ & & & \\
\hline GW-742 & $\mathrm{CR}$ & . & . & $\bullet$ \\
\hline GW-745 & $\mathrm{EF}$ & . & . & $\bullet$ \\
\hline GW-751 & $\mathrm{EF}$ & . & . & $\bullet$ \\
\hline GW-753 & EF & . & . & $\bullet$ \\
\hline GW-755 & EF & . & $\bullet$ & . \\
\hline GW-758 & $\mathrm{EF}$ & . & $\bullet$ & . \\
\hline GW-760 & $\mathrm{EF}$ & . & . & $\bullet$ \\
\hline GW-764 & EF & . & . & . \\
\hline GW-766 & EF & . & . & $\bullet$ \\
\hline GW-768 & $\mathrm{EF}$ & . & $\bullet$ & . \\
\hline GW-773 & $\mathrm{EF}$ & . & . & $\bullet$ \\
\hline GW-794 & $\mathrm{BC}$ & . & . & $\bullet$ \\
\hline GW-803 & EF & . & $\bullet$ & . \\
\hline GW-804 & EF & . & $\bullet$ & . \\
\hline GW-811 & $\mathrm{BC}$ & . & $\bullet$ & 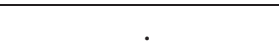 \\
\hline GW-812 & $\mathrm{BC}$ & . & $\bullet$ & . \\
\hline GW-813 & $\mathrm{BC}$ & . & $\bullet$ & . \\
\hline GW-814 & $\mathrm{BC}$ & . & $\bullet$ & . \\
\hline GW-815 & $\mathrm{BC}$ & . & $\bullet$ & \\
\hline GW-819 & EF & . & $\bullet$ & \\
\hline
\end{tabular}

Notes:

1. BC - Bear Creek Hydrogeologic Regime

CR - Chestnut Ridge Hydrogeologic Regime

EF - Upper East Fork Poplar Creek Hydrogeologic Regime

2. Unknown/Inadequate Well Construction - design and construction details for the well are not available or do not meet the technical standards of the GWPP, including wells that do not meet other GWPP requirements (e.g., all-weather access).

Low Priority/Need for Additional Monitoring Data - based on the location of the well and available monitoring data, there is no compelling priority or need to obtain additional groundwater quality and/or hydrologic monitoring data to serve the current technical objectives or programmatic purposes of the GWPP.

Well Redundancy Evaluation - continued use of the well for groundwater quality sampling and hydrologic monitoring was discontinued based on results of quantitative statistical evaluation of "well redundancy" as described in respective reports documenting the baseline assessment (BWXT 2005) and supplemental assessment (B\&W Y-12 2009) of the GWPP.

“.” - - Criteria not applicable for specified well 
APPENDIX C

ADDENDA

(if issued) 


\section{(-SAMPLE-) \\ ADDENDUM TO THE \\ 'Y-12 GROUNDWATER PROTECTI ON PROGRAM \\ MONI TORI NG OPTI MI ZATI ON PLAN (MOP) \\ FOR GROUNDWATER MONI TORI NG WELLS"}

(Y/TS-2031/ R2 - Nov. 2013)

Date Created :

Addendum No. :

\begin{tabular}{|l|l|l|l|l|l|l|}
\hline \multirow{2}{*}{ Revision Type } & \multicolumn{2}{|c|}{$\begin{array}{c}\text { MOP Status } \\
\text { Designation }\end{array}$} & \multirow{2}{*}{ Well No. } & Regime & $\begin{array}{c}\text { Table \# } \\
\text { Appendix B of } \\
\text { MOP }\end{array}$ & $\begin{array}{c}\text { Primary } \\
\text { Criteria }^{2}\end{array}$ \\
\cline { 2 - 6 } & Active & Inactive & & & & \\
\hline ADD well to MOP & & & & & & \\
\hline REMOVE from MOP3 & & & & & & \\
\hline $\begin{array}{l}\text { CHANGE Well Status } \\
\text { Designation to }{ }^{4}:\end{array}$ & & & & & & \\
\hline $\begin{array}{l}\text { CHANGE Primary } \\
\text { Criteria to: }\end{array}$ & & & & & & \\
\hline
\end{tabular}

${ }^{1}$ Hydrogeologic Regimes

BC - Bear Creek

CR - Chestnut Ridge

EF - Upper East Fork Poplar Creek

${ }^{2}$ Primary Criteria for determining Status Designation (reference MOP)

Active Status

REG - Regulatory Program (-RCRA, -CERCLA, -SWDF)

DTW - Hydrologic Monitoring

DOE - DOE Surveillance Program

Inactive Status

WC - Well Construction

LP - Low Priority

RE - Redundancy Evaluation

${ }^{3}$ Any groundwater well monitoring location officially removed from the Y-12 GWPP MOP must have a P\&A Request number or otherwise stated below.

${ }^{4}$ This is a change in the well status designation. Well status designation is defined for each well in the MOP as either active or inactive status. The GWPP manager is the only one with authority to make an official change in well status designation (see below).

\section{REASON FOR MODI FI CATION:}

\section{CHANGE I N WELL STATUS DESI GNATI ON (Please initial one):}

For the well(s) listed above, I hereby amend the MOP and change the status designation of the well(s) from active (App. B, Table 1) to inactive status (App. B, Table 2)

For the well(s) listed above, I hereby amend the MOP and change the status designation of the well(s) from inactive (App. B, Table 2) to active status (App. B, Table 1) for the regime listed above 


\section{DISTRIBUTION:}

V. J. Brumback

T. S. Bunch (RSI)

T. K. Cothron

J. D. Darby (DOE - EM)

J. P. Donnelly (NNSA-YSO)

S. M. Field

H. K. Haase

T. R. Harrison (Elvado)

C. C. Hill

Y-12 Records Services
W. K. Jago (SAIC)

S. B. Jones

S. W. King

R.H. Ketelle

D. R. McDaniel

S. E. McNamara

L. K. Rawlins

J. E. Sebastian (TDEC-DOE-O)

E. R. Schultz
L. M. Sims (RSI)

L. O. Vaughan

J. R. Walker (Elvado)

D. B. Watson (UT-Battelle) 


\section{DISTRIBUTION}

\section{U.S. DEPARTMENT OF ENERGY}

J. P. Donnelly

B\&W Y-12, LLC PROGRAM MANAGEMENT

D. R. McDaniel

ENVIRONMENTAL COMPLIANCE DEPARTMENT

V. J. Brumback

T. K. Cothron

S. M. Field

C. C. Hill

S. B. Jones

E. R. Schultz

S. E. McNamara

L. O. Vaughan

INFORMATION TECHNOLOGY

S. W. King

9114DMC-01971865.6550-RC

Y-12 Records Services (Electronic copy- OSTI)

YDCC - RC
TENNESSEE DEPARTMENT OF

ENVIRONMENT AND CONSERVATION

DOE OVERSIGHT

J. E. Sebastian

ELVADO ENVIRONMENTAL LLC

T. R. Harrison

J. R. Walker

RESTORATION SERVICES, INC

T. S. Bunch

H. K. Haase

R. H. Ketelle

L. M. Sims

File-EMEF-DMC

UT-BATTELLE, LLC

D. B. Watson 